\title{
A PLANNER'S GUIDE: CONSERVING BRUTALIST AND CONCRETE MODERN ARCHITECTURE IN TORONTO
}

by

Kristen Flood

BA, University of Kings College, 2012

A Major Research Paper

presented to Ryerson University

In partial fulfillment of the requirements for the degree of

\author{
Master of Planning \\ in \\ Urban Development
}

Toronto, Ontario, Canada, 2014

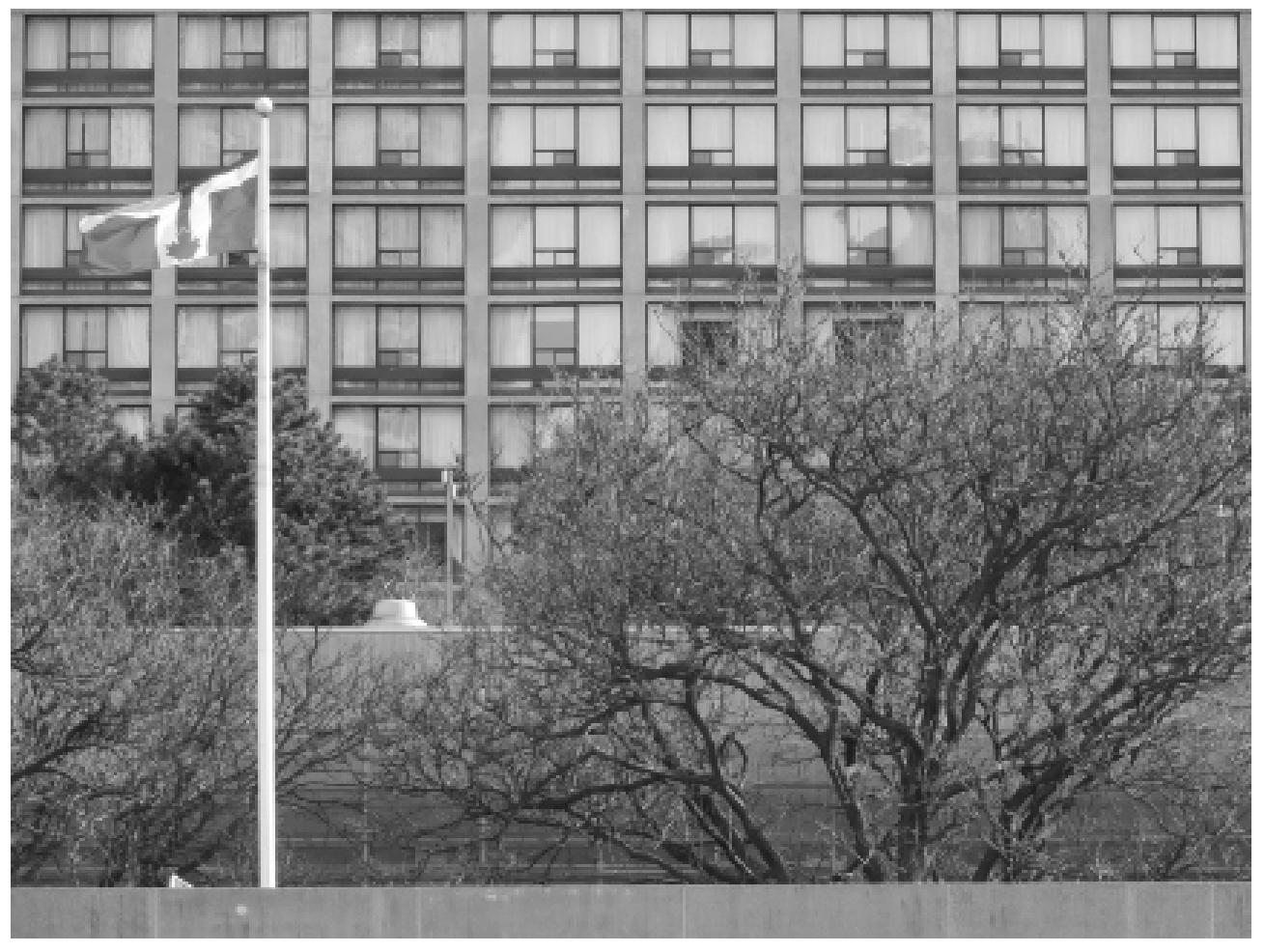

(C) Kristen Flood 2014 
I hereby declare that I am the sole author of this MRP. This is a true copy of the MRP, including any required final revisions.

I authorize Ryerson University to lend this MRP to other institutions or individuals for the purpose of scholarly research.

I further authorize Ryerson University to reproduce this MRP by photocopying or by other means, in total or in part, at the request of other institutions or individuals for the purpose of scholarly research.

I understand that my MRP may be made electronically available to the public. 


\title{
A Planner's Guide: Conserving Brutalist and Concrete Modern Buildings in Toronto Master of Urban Planning
}

(C) Kristen Flood, 2014

Master of Planning

in

Urban Development

Ryerson University

\begin{abstract}
This guide establishes a rationale and presents tools and best practices for the conservation of Brutalist and concrete modern heritage in Toronto. Brutalism and concrete modernism are valuable because they are architecturally compelling and they evoke the ethics and the politics of the postwar period. In Toronto there are many Brutalist and concrete modern civic buildings, infrastructure, university buildings, cultural institutions, buildings built through capitalist investment and high-rise towers. These buildings have architectural and cultural heritage value and they should be protected. Planners should leverage the emerging international movement for the protection of Brutalist and concrete modern buildings to support the case for conservation. Conservation tools include advocacy and education, legal protection through policy and adaptive re-use.
\end{abstract}

Key Words: architecture, concrete, modern, Brutalist, postwar, Toronto, historic conservation 


\section{Acknowledgements}

I wrote this paper with the editing, guidance and support of my professor and supervisor Nina-Marie Lister. Graeme Stewart provided insight and encouragement. 


\section{Table of Contents}

\section{Introduction p. 1}

\section{Part 1: Buildings}

Chapter 1: Introduction to Brutalism p. 3

Chapter 2: Aesthetic p. 4

Chapter 3: Concrete: The Material of Choice p. 5

\section{Part 2: Context}

Chapter 1: Soviet Architecture p. 7

Chapter 2: British Civic Architecture p. 9

Chapter 3: Introduction of Brutalism to the World p. 10

Chapter 4: Key Architects p. 11

Chapter 5: The Dispersal of Brutalism p. 14

\section{Part 3: Toronto}

Chapter 1: North American Context p. 16

Chapter 2: Toronto Context p. 17

Chapter 5: Key Examples p. 19

Chapter 4: Building Types p. 31

\section{Part 4: Conservation}

Chapter 1: Conserving Brutalist Heritage p. 33

Chapter 2: Changing Approaches to Conservation p. 34

Chapter 3: Rejection of Modernism p. 36

Chapter 4: Policy Tools p. 37

Chapter 5: Best Practices p. 41

Chapter 6: Recommendations p. 44

\section{Conclusion p. 48}




\section{List of Figures}

1. Toronto Flag and Sheraton Centre [Personal photograph taken in Toronto]. (2014, April 1).

2. Robarts Library Vertical [Personal photograph taken in Toronto]. (2014, March 22).

3. Weathered Concrete [Personal photograph taken in Toronto]. (2014, April 1).

4. Gosplan Garage: General View. 1936. State Museum of Architecture, Moscow, Moscow. Art Blart. Web. 12 Apr. 2014. <http://artblart.com/tag/russian-constructivism/>.

5. Alison \& Peter Smithson, Robin Hood Gardens, London, 1964-70. N.d. London. Critic Under the Influence. Web. 12 Apr. 2014. <http://criticundertheinfluence.wordpress.com/ category/lectures/>.

6. The cover of the exhibition catalogue of Parallel of Life and Art [Photograph found in The Independent Group]. (n.d.). In The Independent Group. Retrieved March 19, 2014, from http://independentgroup.org.uk/contributors/smithson/index.html

7. Bruckels, M. (n.d.). Unite d'abitazione a Berlino. In Wikimedia Commons. Retrieved March 19, 2014, from http://it.wikipedia.org/wiki/File:Corbusierhaus_Berlin_B.jpg (Originally photographed 2010)

8. Freedman, L. (2012). Yale University Art Center, New Haven [Photograph found in Louis I. Kahn Collection, The University of Pennsylvania and the Pennsylvania Historical and Museum Commission, New Haven]. In Netherlands Architectural Institute. Retrieved April 3, 2014, from http://en.nai.nl/content/1286453/kahns_designs (Originally photographed 1953)

9. Toronto Flag and Sheraton Centre [Personal photograph taken in Toronto]. (2014, April 1).

10. Key Map [Personally Created Using Google Maps Satellite Image]. (2014, April 1).

11. CN Tower Plaza [Personal photograph taken in Toronto]. (2014, March 31).

12. Gardiner Expressway construction [Photograph found in City of Toronto Archives, Toronto]. (n.d.). In Fort York and Garrison Common Maps. Retrieved April 3, 2014, from http://fortyorkmaps.blogspot.ca/2013/03/1959-star-new-plans-for-gardiner. html (Originally photographed 1961)

13. OISE Windows [Personal photograph taken in Toronto]. (2014, March 22).

14. Central Tech Art Centre Classrooms [Personal photograph taken in Toronto]. (2014, March 31).

15. Manulife Centre Retail [Personal photograph taken in Toronto]. (2014, March 22).

16. St. James Town Context [Personal photograph taken in Toronto]. (2014, April 1).I 
17. New City Hall [Personal photograph taken in Toronto]. (2014, April 3).

18. CN Tower [Personal photograph taken in Toronto]. (2014, April 3).

19. Gardiner Expressway [Personal photograph taken in Toronto]. (2014, April 3).

20. OISE [Personal photograph taken in Toronto]. (2014, March 22).

21. Robarts Library Horizontal [Personal photograph taken in Toronto]. (2014, March 22).

22. Ontario Science Centre [Photograph found in Toronto]. (n.d.). In Wikipedia. Retrieved April

2, 2014, from http://en.wikipedia.org/wiki/Ontario_Science_Centre (Originally photo graphed 2006, September 21)

23. Central Tech Art Centre [Personal photograph taken in Toronto]. (2014, March 31).

24. Sheraton Centre [Personal photograph taken in Toronto]. (2014, April 1).

25. Manulife Centre [Personal photograph taken in Toronto]. (2014, March 22).

26. Collonade [Personal photograph taken in Toronto]. (2014, March 22).

27. St. James Town [Personal photograph taken in Toronto]. (2014, April 1).

28. Library Journal. (2008, May 29). Retrieved April 3, 2014, from http://lj.libraryjournal. com/2008/05/people/lama-and-iida-announce-winners-of-library-interior-designcompetition/

29. Museum and its Surroundings. (2008, July 9). In CIL Summer Tour to Europe 08. Retrieved April 3, 2014, from http://ciltour08.wordpress.com/category/journal/

30. Robarts Library Context [Personal photograph taken in Toronto]. (2014, March 22).

30. Tower Mural [Personal photograph taken in Toronto]. (2014, March 23). 
Brutalist architecture presents a new challenge to heritage planners in Toronto. This guide encourages planners to preserve Brutalist and concrete modern architecture by first establishing their value through a comprehensive overview of the movements and then arguing for their conservation. To successfully preserve Brutalist and concrete modern buildings planners must understand their unique value and the cultural and historical influences that led to their construction. The influences and historical circumstances that informed Brutalism and concrete modernism are presented and an overview of the aesthetic and ethical nature of the movements is provided. This definitional work serves to promote the benefits and appeal of buildings that are often underappreciated and sometimes disliked. Casting Brutalism and concrete modernism in a positive light is a difficult task, but arguing for their preservation is even harder.

It is counter-intuitive to advocate for the preservation of buildings that were built based on a philosophy that promoted the new at the expense of the old. Concrete modern developments were sometimes constructed in the wake of the demolition of Victorian buildings. Other Brutalist and concrete modern buildings did not physically displace the past but did so metaphorically through design that subverts historic forms of architecture. This disregard for past approaches makes preserving Brutalist and concrete modern buildings contradictory and difficult to defend. If these buildings are not defended, however, they will not remain.

Brutalist and concrete modern buildings were built to usher in a new era but today, they have begun to age and new forms have replaced them. The increasing age and disrepair of these buildings combined with a lack of public appreciation have jeopardized their futures. Furthermore, in Toronto the pressure to develop has made preservation in general a difficult task. Toronto has many significant Brutalist and concrete modern buildings that are at risk of being altered, abandoned or torn down if they are not recognized as valuable. Toronto came of age in the postwar era and Brutalist and concrete modern buildings define the city's streets but the city also has a history of disregarding its past. Toronto planners must recognize the importance of modern 
CONSERVING BRUTALIST AND CONCRETE MODERN HERITAGE

heritage and advocate for its preservation through the use of policy tools and preservation best practices. Now is the time to defend Brutalism and concrete modernism because the majority of these buildings in Toronto are still intact. However, if planners and the public do not come to understand and embrace these buildings, this period of Toronto's history will soon vanish from our collective memory.

Brutalist and concrete modern buildings are important testaments to the values, ideas and aesthetic of the postwar period in Toronto and the need for their preservation is pressing. To ensure that these buildings are protected planners must use existing policy tools like the Ontario Heritage Act 1990 and innovate new approaches. Otherwise, despite the arguments in favour of their protection, these buildings will face uncertain futures. It is the responsibility of planners to use their positions as stewards of urban form to conserve Toronto's historical architecture. 


\section{Buildings}

\section{Introduction to Brutalism}

From monumental city halls to imposing university libraries, Brutalist buildings are often commissioned by governments and institutions to fulfill important civic functions. Therefore Brutalist buildings prioritize utility and scale and forego adornment and embellishment. Brutalist architecture and the iterations that followed define the postwar period and they define Toronto a city that underwent major development in the 1950s, 60s and 70s. Brutalism did not originate in Toronto; rather, it is a product of England, but its popularity led to the international dispersal of Brutalist ideas. Brutalism is a show of force. Many people dislike Brutalist buildings because they diminish the importance and comfort of the individual in exchange for affordable and useful collective spaces. Mark Kingwell (2008), a well-known Toronto philosopher, cultural critic and author of Concrete Reveries writes: "Surely much of the hostility we feel toward concrete is owing to the Brutalist annexation of its loveliness, the way it was taken over and made into those thick, tough slabs that block out the sky" (p. 4). Kingswell's dislike of Brutalism has to do with its aesthetic expression but to isolate Brutalist aesthetics from Brutalist ethics is to misunderstand the movement. The aesthetics of Brutalism are informed by political motivations: "Formally, Brutalism's modular spaces manifested a social desire for a standardized society - cultural cohesion, shared values, and a fair quality of life for all" (Self, 2013, p. 29, Brutalism). The primary goal of the Brutalist movement is ethical: it has its "roots in the programmatic needs of a society" (Vidler, p. 17, 2013, Brutalism). Brutalist buildings are venues where people go to learn and access services rather than admire attractive design.

The ethics of Brutalism are tied to the aesthetic choices made by Brutalist architects. Concrete is their material of choice. Concrete is durable, affordable and commanding, making it ideal for government and institutional buildings. Because of its affordability and wide availability, concrete has been frequently used in modern architecture although it has always been in dialogue with glass - glass gained popularity as a construction material around the same time as concrete. Unlike glass, concrete can be domineering and overpowering but it is more 


\section{CONSERVING BRUTALIST AND CONCRETE MODERN HERITAGE}

practical and its mutability offers unique creative advantages.

Today, concrete evokes the recent past. It is everywhere in Toronto and yet it is no longer of the moment. Despite recent advances in concrete technology that have given it various potential properties including transparency, flexibility and sustainability, concrete retains its associations with postwar architecture (Petricone, 2012). Brutalist architecture was experimental and innovative and it fulfilled important civic functions. The concrete modern architecture that Brutalism inspired is expressive and thoughtful - it is the product of a generation that was concerned with defining the future and moving forward. Together, these two overlapping movements defined a unique historical moment of architectural expression and prolific production. Both Brutalist buildings and the many concrete modern iterations they inspired, require a dedicated preservation and planning effort if they are to remain aesthetic and functional parts of the contemporary city.

\section{Aesthetic}

Brutalist buildings stand out in the urban fabric. They are concrete, towering structures that fail to blend in with their surroundings. The imposing nature of Brutalist buildings has domineering connotations. Brutalist buildings project human imagination onto the urban landscape: they often challenge gravity through inverted proportions and unusual massing. This distinctly human-made aspect of Brutalism is not linked to the artisanal traditions of earlier eras but to mechanization. Single pour concrete structures were made possible through technical innovation that was not available to previous generations. New technology enabled leading architects of the modern movement to redefine aesthetic norms and push the architectural envelope by experimentating with new forms.

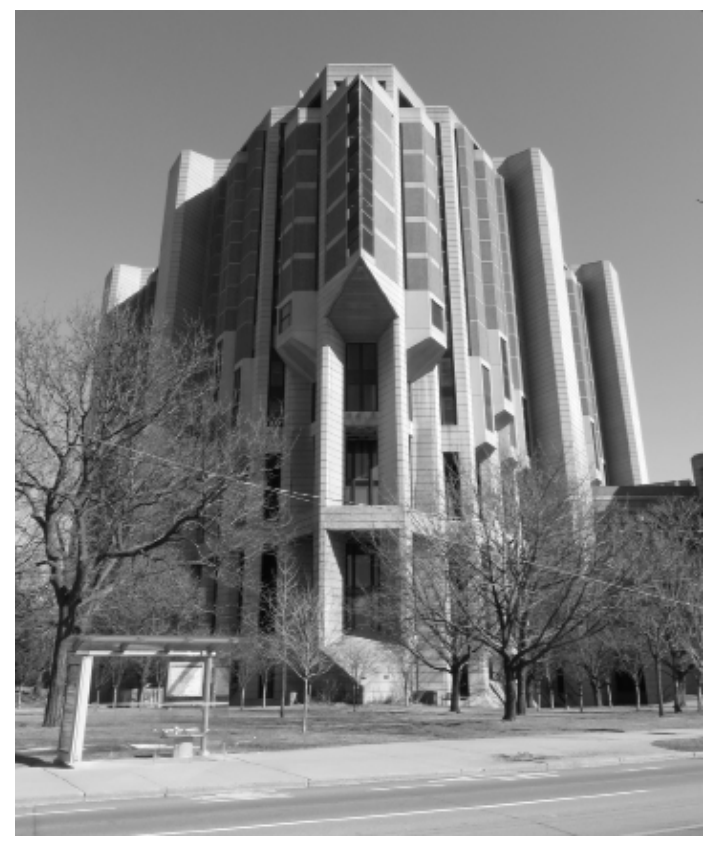


Brutalism falls under the broad category of modern architecture. However, there is conflict within modern architecture between Brutalism and the glass towers of high modernist buildings. Modern architecture in general was influenced by Japanese architecture:

Japanese Architecture seduced the

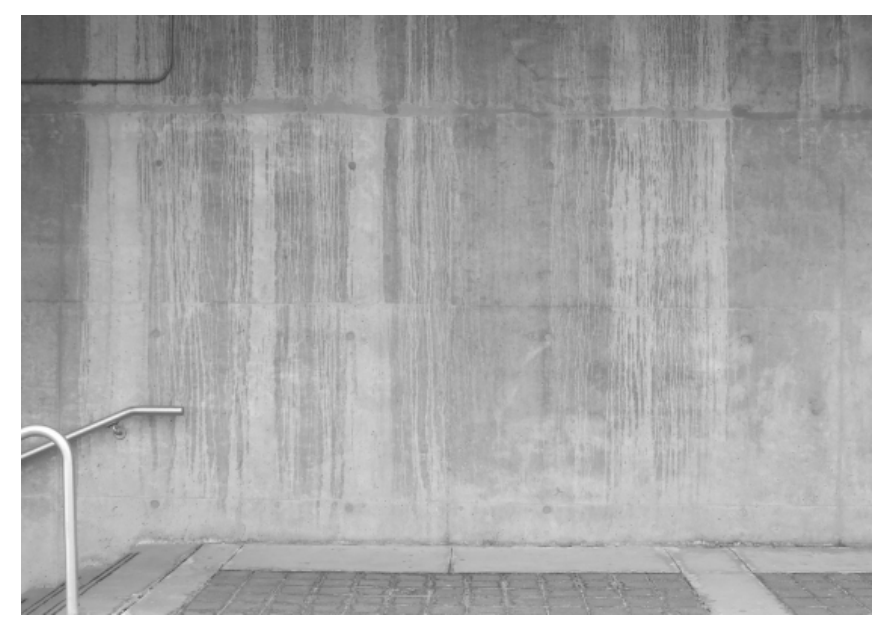
3. generation spanning 1900, producing in Frank Lloyd Wright, the open plan and an odd sort of constructed decoration; in Le Corbusier, the purist aesthetic-the sliding screens, continuous space, the power of white and earth colors; in Mies, the structure and the screen as absolutes. Through Japanese Architecture, the longings of the generation of Garnier and Behrens found FORM (Crosby, 1955 p. 18).

The simplicity of modern architecture and its honest use of raw materials owe a debt to Japanese architecture. Japanese architecture also points to the link between glass and concrete - both materials are raw, simple and honest.

\section{Concrete: The Material of Choice}

Concrete is affordable, rugged and quintessentially modern. At the time when Brutalism emerged, concrete was a relatively new building material. Concrete is made of particles of sand and stone that are bound by cement. Concrete was considered to be durable and it has been commonly used in the Mediterranean climate, however, in other climates it has not stood the test of time (Petricone, 2012, p. 11). Concrete infrastructure all over the world is crumbling and graffiti is a constant concern. Today, weathered concrete covered in graffiti evokes a distinctly urban image but it is also a distinctly modern image. Brutalist architects used concrete because they thought it was indestructible but it has revealed its fallibility over time. Concrete has significant advantages though and it continues to be a relevant material. One of the most significant advantages of concrete is its malleability, which allows architects to express their vision in new, creative ways.

There are two techniques that architects and engineers use to design and build concrete 
CONSERVING BRUTALIST AND CONCRETE MODERN HERITAGE

structures: in situ concrete structures are made with single pours and assembled concrete structures are made with pre-cast panels that are poured in advanced and assembled onsite. While in situ concrete has a sense of authenticity and it showcases the malleability of the material, pre-cast concrete allows for flexibility, mass-production and surface detailing. The main advantage of pre-cast panels is that they can be mass-produced "making affordable the ambitious housing, education, and health projects of the Welfare State" (Calder, 2013, p.46, Brutalism). Peter Smithson (1959, republished in 2011) remarks that the difference between in situ and pre-cast concrete is that each evokes the scale of the machine that made it:

if a building is made of pre-cast elements, or concrete blocks, the building has to reflect the way it was built, and inevitably the building will not only have a different scale from an architecture that is conceived of as being a single object made by a machine, but it will be built at the scale of the genuine machine with which it was built (p. 39).

The unique proportions and scale of Brutalist buildings were made possible by advances in technology and Brutalists celebrated the mechanical production of concrete as a symbol of progress. 


\section{Context}

\section{Soviet Architecture}

The utilitarian approach and social values that characterize Brutalism emerged in architecture in the Soviet Union. Communism was the driving force behind all production, both artistic and functional, in the Soviet Union. Soviet architecture was defined by its social, political and public focus: "It is to the social

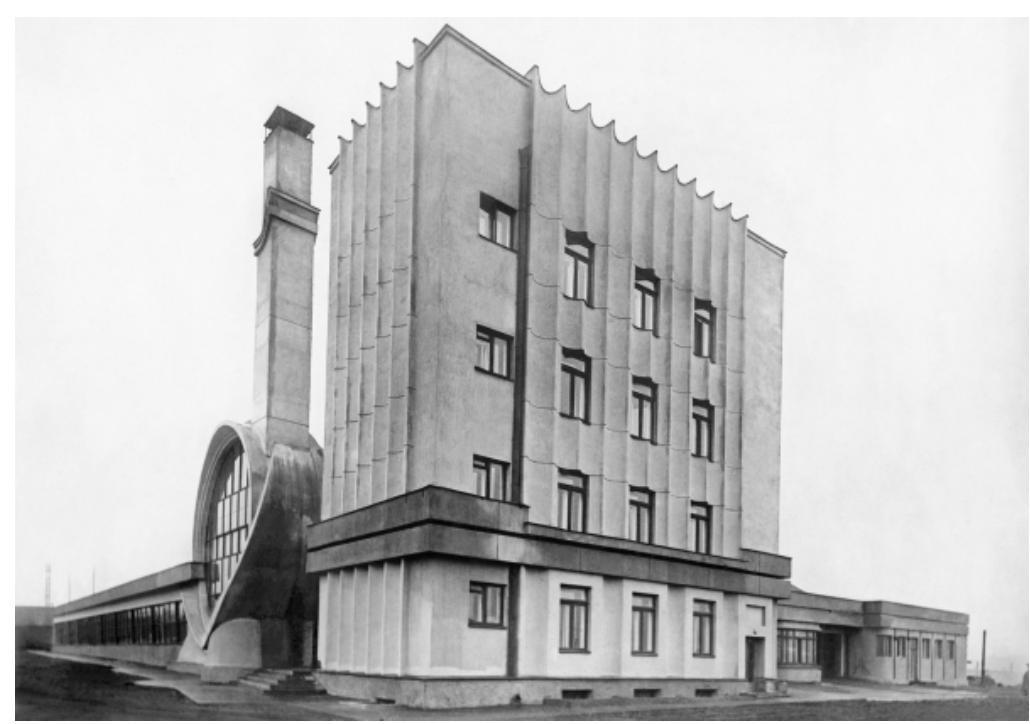

Gosplan Garage, Located on the Outskirts of Moscow, Designed by Konstantin Melnikov in 1936

revolution [of October 1917], rather than to the technological revolution that the basic elements of Russian architecture are tied" (Lissitzky, 1970, p. 27). The government took a functionalist approach to architecture and used it as a tool to build the country and garner support.

Following World War I, the Soviet Union faced the challenge of rebuilding the country with reduced financial resources. Furthermore, because of drastic political shifts that the Soviet Union underwent at this time, the government wanted to break with the past and rebuild quickly to reassert its authority. This unique set of circumstances led to the belief that, "To be effective and to fulfill our mission in the world, we must accelerate the rate of growth, to force the pace. This can only be accomplished if we do not limit ourselves to what we have inherited but, instead, completely reconstruct it. We must not only build but rebuild" (Lissitzsky, 1970, p. 27).

The dual goals of rebuilding the nation and expressing the ethos of communism spurred a period of development in the Soviet Union in between the wars. Soviet constructivism informed development at this time and laid the groundwork for Brutalism. Constructivism started out as an artistic movement that was primarily concerned with utilitarianism and the promotion of 
CONSERVING BRUTALIST AND CONCRETE MODERN HERITAGE

communism. Because the products of fine arts do not have any utility, they could not be used as communist tools. Therefore, constructivists branched out into clothing design, poster design and architecture. The architectural principles of constructivism are as follows,

Architecture, [Constructivists] maintained, must be stripped of everything that is not rational, not appropriate, and not useful. Every element, every detail of the structure must earn its existence only when it is perfectly useful and economical, only when it has the feeling of a "material awareness," and only when the elements making up the structure can be manufactured on a quantity production basis by machinery (Voyce, 1948, p. 125).

Constructivism is tied to communism in its insistence on utility and focus on production and architecture was used as a creative medium to communicate these values.

Communism determined the uses and the form of Soviet architecture. Individual architects were allowed artistic freedom only within the parameters established by the state. The Soviets believed that architecture should be both highly useful and democratically accessible. The government viewed architecture as a tool to build "theaters and museums that will serve the masses, provide decent housing, schools, libraries, club houses, hospitals, and stadiums for the people" (Voyce, 1948, p. 130). Architects designed the form of these structures to reflect the dynamism of a communist nation. The worker is central to communist theory and the inspiration for the dynamic design that came out of the Soviet Union: "They were experimenting with the juxtaposition of different geometrical forms ... Daring innovation has been shown in the treatment of solids and voids, in the use of sharply conflicting masses and forms. Diversity of directions and contrast in materials are ingeniously handled" (Voyce, 1948, p. 142). In between the wars, the Soviet Union underwent a period of redefinition both politically and artistically. Simultaneously, new policies were implemented and new approaches to design were tested.

Many of the experimental design elements of Soviet architecture are echoed in Brutalist architecture. Furthermore the social ideals that are the foundation of Soviet architecture also inform Brutalist architecture. Despite the tense relationship between the Soviet Union and other nations, communist ideas were still being tested through architecture in Britain and 
North America. The circumstances that led to the building boom in the Soviet Union in the 1930s were similar to those that led to the building boom in England after World War II, but the political ideologies that informed the building efforts were divergent.

\section{British Civic Architecture}

Brutalism emerged as a distinct architectural style in England; after World War II: "The scale of the devastation was vast, and Brutalism emerged as a tool of state-led reconstruction" (Self,

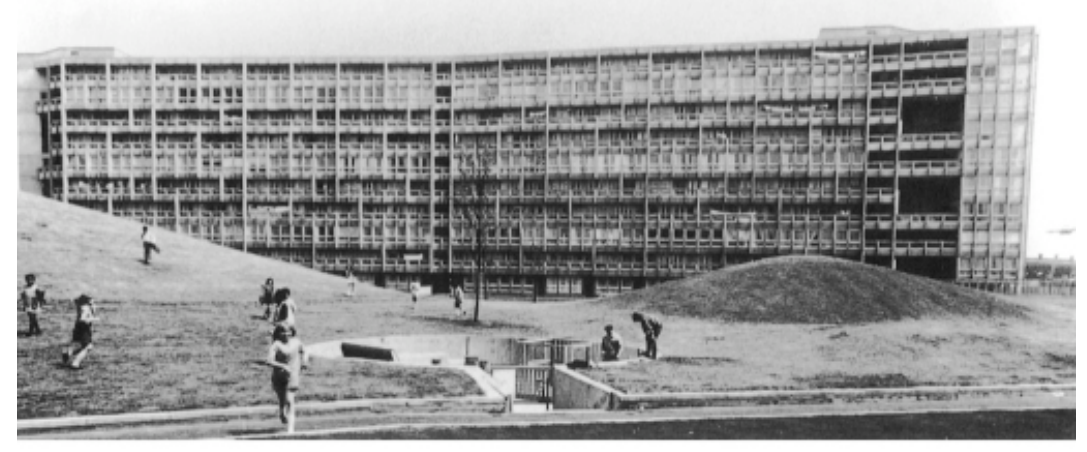

Robin Hood Gardens - Council in London Housing Designed by Alison and Peter Smithson 2013, p.29). Brutalism was popularized as a strategy for rebuilding on a citywide scale but it was also a forward-looking statement about the future. Brutalism was used to wipe the slate clean and prepare England to transition into a class-less society impervious to the economic depression it suffered in the 1930s. The re-definition and rebuilding of England went hand-inhand.

Brutalism began as a public form of architecture and its civic roots define the movement. Many large-scale institutions - from museums, to schools, to city halls - were built in the Brutalist style. For this reason, Brutalist buildings are monumental and somewhat monastic: they were built to serve collective purposes and provide public services rather than to enhance the comfort and enjoyment of individuals. Andrew Kovacs and Aleksander Bierg (2013) describe Brutalism as design by committee; "bureaucracies [could] legitimize their presence within the city by employing stoic mass" (p. 31, Brutalism). English bureaucracies commissioned Brutalist buildings to restore order and rebuild the nation and this mission is expressed through architecture.

Shortly after its emergence, the hallmark style of Brutalism spread to the private sector and the movement was ultimately subsumed by concrete modernism. Many hotels, shopping malls, 


\section{CONSERVING BRUTALIST AND CONCRETE MODERN HERITAGE}

and apartment complexes were built in the concrete modern style that shares the weight and might of Brutalism but not the ethics. What was first a movement borne of necessity became a way for cities, particularly those in North America, to grow as they prospered in the economic boom that followed the war. Despite its dispersal and dilution, the appeal of Brutalism remained the same: large structures made with cheap materials and designed in a new style. True Brutalism, however, is about both ethics and aesthetics and at its core it is a civic form of architecture. In this sensibility, Brutalism is about city building: it is architecture with a purpose.

\section{Introduction of Brutalism to the World}

Reyner Banham wrote one of the first essays on Brutalism in 1955. The essay identifies New Brutalism as an architectural movement and Banham situates the movement in terms of both art history and modern architecture. He does not view Brutalism as an ethical movement, but as an aesthetic/architectural movement that is an offshoot of modern architecture. He uses the term "New Brutalism" with the "New" having since dropped from common usage.

While modern architecture is noted for its use of metal and glass and Brutalism for its use of concrete, Banham describes how both architectural approaches share "honesty in structure and materials," which is "one of the basic moral imperatives of the Modern Movement" (Banham, 1955, p. 12, Brutalism). While Brutalism is of-its-time and Banham's essay is an attempt to situate Brutalism in history, he also recognizes that Brutalism is a departure from the past: New Brutalists "have stopped speaking to Mansart, to Palladio and to Alberti” (Banham, 1955, p. 15, Brutalism). Banham framed Brutalism within the history of architecture to make it more understandable but like modern architecture in general, Brutalism is not defined by its relationship with the past; Brutalists self-consciously rejected the adornment of historical forms of architecture and broke

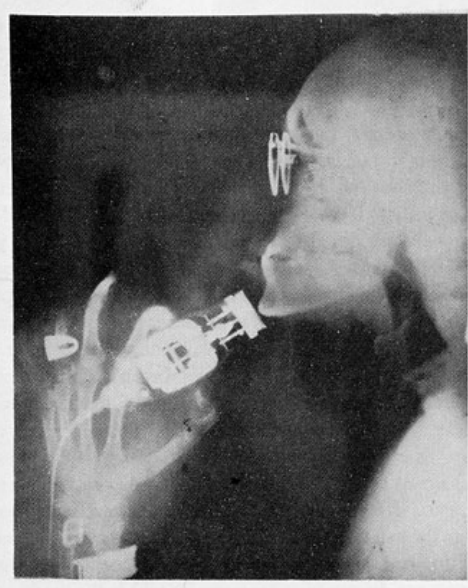

catalogue of the exhibition

Parallel of Life and Art Held at the Institute of Contemporary Arts September 1th to october 18th, 1953. 
with tradition.

Banham introduced Brutalism to a wide audience but the movement itself predates his description. One of the earliest expressions of Brutalism is the exhibition Parallel of Life and Art. Two pioneering British Brutalist architects, Alison and Peter Smithson, along with the artists Edouardo Paolozzi and Nigel Henderson, curated the exhibition, which was held at the Institute of Contemporary Arts in 1953. The individuals who were involved in the exhibit were part of the Independent Group, which was formed based on their shared interest in found art (theindependentgroup.org.uk). The exhibition was not well received and many critics decried the move away from traditional notions of beauty and the picturesque (Banham 1955, Brutalism). This criticism is correct. Brutalism is not concerned with beauty, which is not to say that it is not concerned with aesthetics. Brutalism's "bloody-mindedness" as Banham refers to it, defined the style.

\section{Key Architects}

\section{Alison and Peter Smithson}

Friends of Banham, Alison and Peter Smithson helped define Brutalism. The British architects are responsible for some of the first large-scale, Brutalist concrete structures in England. They coined the term "Brutalism" in 1953 when describing the personal architectural style that they developed for the design of their house (Highmore, p.19, 2013, Brutalism).

The Smithsons founded Brutalism and they also helped to shape the conversation that emerged around the movement. They situated Brutalism as an ethical form of architecture. In Architectural Digest in 1957 they wrote, "Brutalism tries to face up to a mass-production society, and drag a rough poetry out of the confused and powerful forces which are at work. Up to now Brutalism has been discussed stylistically, whereas its essence is ethical" (p. 113, republished 2011, p, 37). In a later conversation the couple had with the architect Maxwell Fry, Alison Smithson emphasizes that Brutalism is concerned with society: "We are interested in expressing not ourselves, but what is going on and building which denies what is going 
CONSERVING BRUTALIST AND CONCRETE MODERN HERITAGE

on is just the opposite of brutalism" (originally published in Architectural Digest, 1957, p, 76, republished 2011, p. 42). Through their dialogue on the intentions of Brutalism, the Smithsons crystallized its meaning.

\section{Denys Lasdun}

Denys Lasdun is a British architect who experimented with form through his use of concrete. Lasdun is often cited as a Brutalist architect but during his career, which spanned from the 1930 s to the 1960 s, his style shifted. Lasdun's work, especially in the 1960 s, was seen as a leading example at the time. Some architectural historians reject the classification of architects into movements:

Lasdun has never fitted into the over-tidy pigeon holes used to chart the history of modern architecture. In the 1950s, he remained aloof from the polemics of the "new brutalism" (much discussed at the time), and diverged from that 'anonymous functionalism' seen by some as the true way of modernism in Britain (Curtis, 1999, p. 10).

Despite William J.R. Curtis's reluctance to categorize Lasdun's work as Brutalist, Lasdun's architecture expresses Brutalist ideas both aesthetically and ethically.

Lasdun designed monumental buildings that have a public presence and concrete was his material of choice. Lasdun explored the range of possibilities that concrete affords; he experimented with form and his buildings have a striking abstract and sculptural presence. Many of Lasdun's iconic buildings were commissioned by government: "More than most British architects of the past few decades, Lasdun has been involved with the design of public buildings or ones requiring a certain honorific presence" (Curtis, 1999, p.12). Lasdun's oeuvre is impressive and visionary and his creative expression and civic focus resonate with the core values of Brutalism.

\section{$\underline{\text { Le Corbusier }}$}

Le Corbusier is a prominent French architect who engaged in Brutalism in a unique and influential way. He worked during the early half of the 20th century and he called his work béton brut rather than Brutalist. Le Corbusier's designs ushered in a new architectural era: 


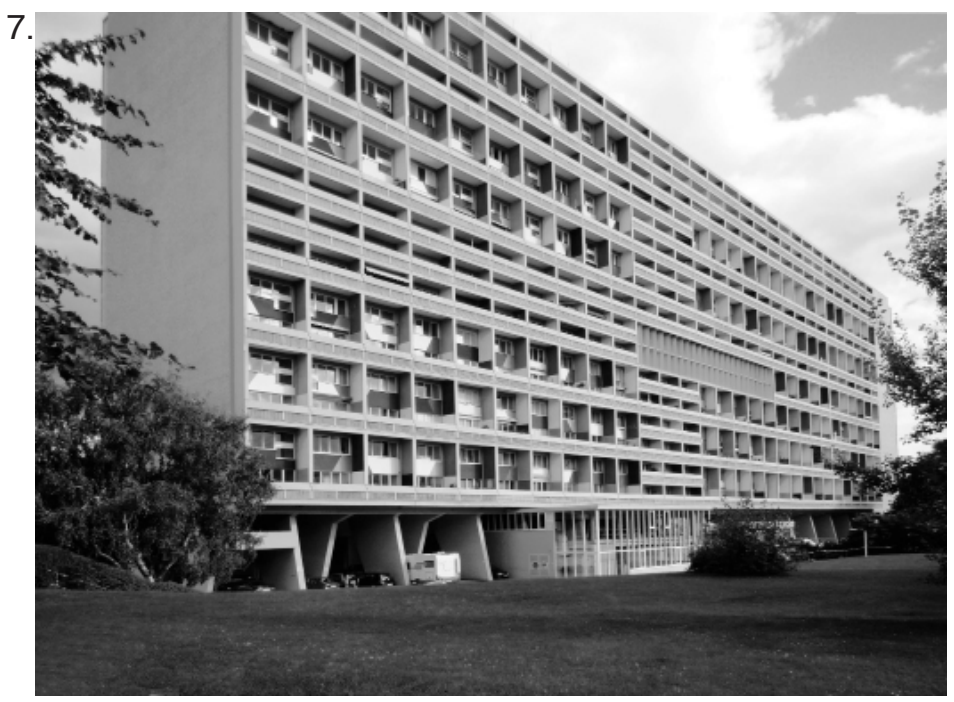

"From the first, his designs for modern houses - he called them 'machines for living' - were strikingly original, and many people were shocked by the spare cubist minimalism of his designs" (LeGates \& Stout, 2000, p. 336).

Le Corbusier worked on large-scale iconic projects all over the world and he is most famous for L'Unite d'Habitation - a mass

housing concept, only one of which was actually built.

Partly because there was an aggravated shortage of cheap places to live and partly for ideological reasons, modernists put mass housing near the top of the conceptual pyramid. ... Le Corbusier was committed enough to this goal for thirty years to design utopian schemes for most European cities. They became paper icons, all were frustrated until a few Unites d'Habitation were commissioned for Marseilles, and one was actually constructed (Jencks, 2005, p. 23).

L'Unite d'Habitation was named for its combination of different uses in a single structure: the building was designed primarily for residential use and it has shops and a hotel on the seventh floor. This mixed-use approach was revolutionary at the time. The design was both praised and decried in the press but it was a popular success (Jencks, 2005, p. 24).

Le Corbusier's vision extended from individual buildings, to designs for whole cities. Le Corbusier planned Chandigarh, the capital city of the states of Punjab and Haryana in India. It was the first planned city in the country although others executed the project (chandigarhtourism.com). His ideas informed other modern mass housing projects all over the world. Ultimately, "Le Corbusier's real impact came not from cities he designed and built himself but from cities that were built by others incorporating the planning principles that he pioneered" (LeGates \& Stout, 2000, p. 336). Many of Le Corbusier's designs were not built but the influence of his thinking has led to the ubiquitous skyscrapers in the park design that has helped to shape the cities of today. 


\section{Louis Kahn}

Louis Kahn was an American architect who helped define Brutalism in the North American context. He wrote an essay in 1944 titled Monumentality that defined his aesthetic and advocated for a return to basic principles; the use of new materials such as steel, concrete, and glass; and standardization.

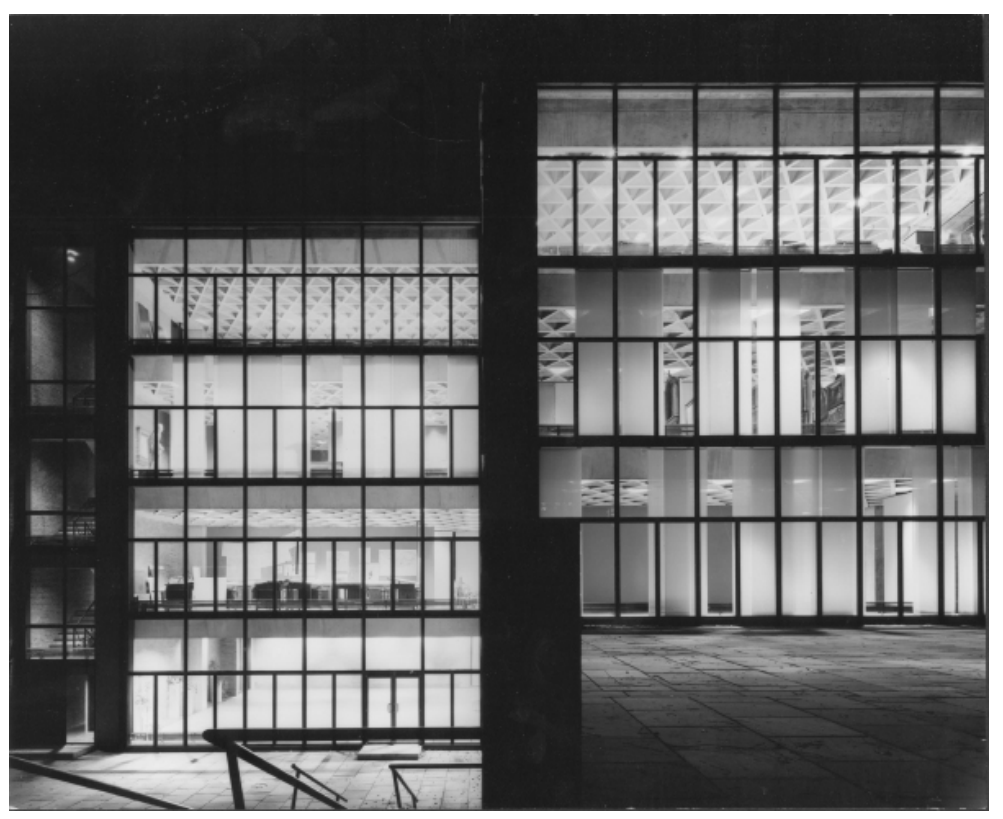

Kahn's architectural style evolved with the times and it is his later work that is classified as Brutalist. One of the pivotal buildings in Kahn's career that expresses his approach to Brutalism is the Yale University Art Gallery and Design Centre, which opened in 1953. The final design for the building is an in-situ concrete structure that has the effect of "uncompromised integrity and force" (Scully, p. 20, 1962). Kahn went on to refine his approach and continue his exploration of concrete as a raw material in later buildings. Kahn's work is defined by his use of materials and his desire to reveal the construction process in a building's final form (Twombly, p. 11, 2003).

\section{The Dispersal of Brutalism}

After its establishment, Brutalism gained widespread popularity and inspired a new stage in modern architecture - the stage of monumentality and concrete. The popularity of Brutalism meant that many architects emulated the work of key architects of the movement. The widespread application of Brutalist ideas led to the end of the Brutalism:

Inevitably - and unfortunately - the "New Brutalism" generated its own following of architects, many of whom seemed content to design à la mode, producing stylized, often over over-scaled buildings that were lacking the definition and simple, refined details exhibited in buildings by Le Corbusier, the Smithsons, Louis Kahn, Denis Lasdun, and others from this period (Johansen, 2013, p. 67, Brutalism). 
CONSERVING BRUTALIST AND CONCRETE MODERN HERITAGE

While Christen Johansen simultaneously accepts and regrets the dispersal of Brutalism, not all buildings that are derivative of Brutalism are lacking; many are significant examples of concrete modern architecture - a more general category that includes spin-off styles of Brutalism.

It is difficult to define the timeframe and the scope of the Brutalist movement because it quickly morphed into other architectural styles: "Brutalism remains a lost movement because it so soon led to other things: to the exposing, accentuating and toughening of the elements of simple direct building and to the very selective attitude to materials" (Cook, 1970, p. 43, Brutalism). Therefore, the term modern is better suited to describe the breadth of postwar concrete architecture than Brutalist although modern architecture is not limited to concrete. However, much of the innovative architecture from the 1950s to the 1970 s was bold concrete design. Brutalism is at the root of modern concrete architecture but it is not synonymous with the iterations it inspired. 


\section{Toronto}

\section{North American Context}

The influences behind architecture are global but architecture is executed on a regional scale. Regional architects designed the majority of Brutalist and concrete modern buildings constructed in the postwar period. These architects were in tune with national politics and values, which both determined the type and number of commissions that were granted and the way that architects approached those commissions.

Brutalism was informed by Soviet architecture and emerged in England because of the unique conditions in that country in the postwar era. A similar set of conditions led to the North American adoption of Brutalism. Like the British, Canadians and Americans witnessed the devastation that World War II wrought in Europe and after the war, politicians were motivated to invest resources at home. North American built form was not affected by bombing like in England, but as a relatively new continent, North America was greatly in need of development to support its population, which was growing with the return of soldiers and the subsequent baby boom.

Brutalism in America and Canada, like Brutalism in England, was used as an architectural tool by governments that needed to construct more buildings to adequately serve the needs of citizens. Furthermore, the principles behind Brutalism resonated in the Canadian context because of Canada's colonial history. Brutalism was transplanted to Canada and then interpreted through North American values. In North America, the "liberal consensus" was the defining ethical attitude of the 1950s, 60s and 70s. The "liberal consensus" is a term that the historian Godfrey Hodgson used to describe "how Americans left and right agreed to expand social programs, education, and infrastructure in the name of progress during the post World War II years" (Rohan, 2013, p. 60). One product of the "liberal consensus" is the urban renewal policies that led to the clearance of large areas of North American cities, which were rebuilt in the modern style. North American governments initiated ambitious development projects based 
CONSERVING BRUTALIST AND CONCRETE MODERN HERITAGE

on shared values and the neoliberal belief that economic growth can be achieved through spending.

In addition to nation building and urban infill, Keynesian capitalism was another motivation behind the building boom in postwar North America. In the 1950s, 60s and 70s spending was encouraged by governments to sustain economic growth. Military spending during World War II broke the economic depression of the 1930s and politicians and economists believed that to continue to prosper, the country must continue to spend. John Maynard Keynes promoted spending through his economic theory, which is based on short-term gains: "if output is running at a high level, firms will employ more men than if it is running at a low level ... Output in turn depends on effective demand" (Stewart, 1972, p. 80). Effective demand is defined as "consumption and investment" (Stewart, 1972, p. 80). This theory led to government spending on development projects, which produced construction and manufacturing jobs and to private investment in buildings that encourage people to spend. Capitalist investment proliferated in postwar North America: numerous hotels, luxury apartments and shopping malls were constructed. Brutalism, was not, however, the architecture of choice for capitalist development projects. These projects were often built in the concrete modern style, which has the affordability and monumentality of Brutalism without the harsh or austere aesthetic.

Brutalist architecture in North America was often used for government, university and other institutional buildings. The style of these buildings is similar to the style of Brutalist buildings in England but the reasons behind the application of Brutalism in North America are based on a unique set of political and ethical circumstances. Furthermore, concrete modern architecture in North America expresses the truth to materials of Brutalism as well as optimism, the liberal consensus and neoliberal economics - factors that are unique to the North American context.

\section{Toronto Context}

Postwar Toronto was developing at a rate that was unmatched by any preceding period.

Suburban sprawl was expanding far beyond the municipal boundary as Scarborough, 
CONSERVING BRUTALIST AND CONCRETE MODERN HERITAGE

Etobicoke, Mississauga and other satellite cities grew. With the advent of sprawl, the importance of the car increased. To accommodate the increase in vehicular traffic, many highway infrastructure projects, like the Gardiner Expressway, were built in the postwar era and they continue to be heavily used today. Education was also heavily invested in at this time leading to the construction of many schools and libraries.

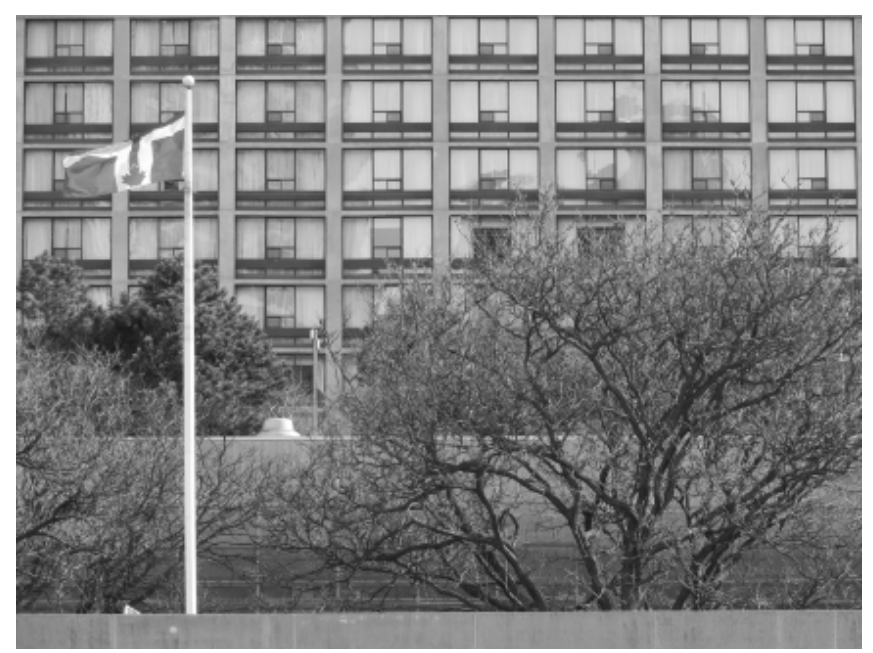

Many of Toronto's iconic buildings are from the postwar period. The city was undergoing the process of defining itself on a national and international scale and architecture was used as a tool to communicate Toronto's presence. The CN Tower communicates Toronto's success both literally and figuratively: the tower functions as a communication antenna that transmits radio signals and it has been depicted on post-cards and key chains as an iconic Toronto landmark. The CN Tower remains one of Canada's most recognizable symbols. New City Hall is another highly visible testament to the ambition and creativity of mid-century Toronto.

The development and self-definition taking place in Toronto were a result of the city's rapid population growth following the war. To accommodate the increase in population, the city increased in density. Tower housing was introduced to the city through urban infill developments and urban renewal policies. The development of tower housing introduced a new type of neighbourhood to the city - the tower in the park, an urban design approach based on the garden city model. These modern neighbourhoods have significant greenspace but, regardless of whether they are located downtown or on the city's periphery, they lack services, restaurants and retail. Toronto also has a wealth of high-density consumer-driven concrete modern architecture - from luxury apartment complexes to towering hotels to cavernous malls. 
CONSERVING BRUTALIST AND CONCRETE MODERN HERITAGE

Postwar Toronto was a booming place - many different types of buildings were being developed to serve people's changing needs and desires. Concrete buildings that express the modern vision of a successful and dynamic urban centre overshadowed the low-rise brick and beam structures of the past. Toronto today retains its modern image but for it to remain a diverse and layered city, its Brutalist and concrete modern heritage must be conserved as part of the story of the city.

\section{Key Examples}

Toronto has many Brutalist and concrete modern buildings and this guide presents a sample of them. The selcted examples are organized into six common types: civic buildings, infrastructure, university buildings, cultural institutions, capitalist investment and tower housing. These categories were chosen because either Brutalist buildings, concrete modern buildings or both often fulfill each use. The examples chosen to illustrate each building type are only a few of many and they were selected for their merit and ability to illustrate the key features of each genre. 


\section{Key Map}

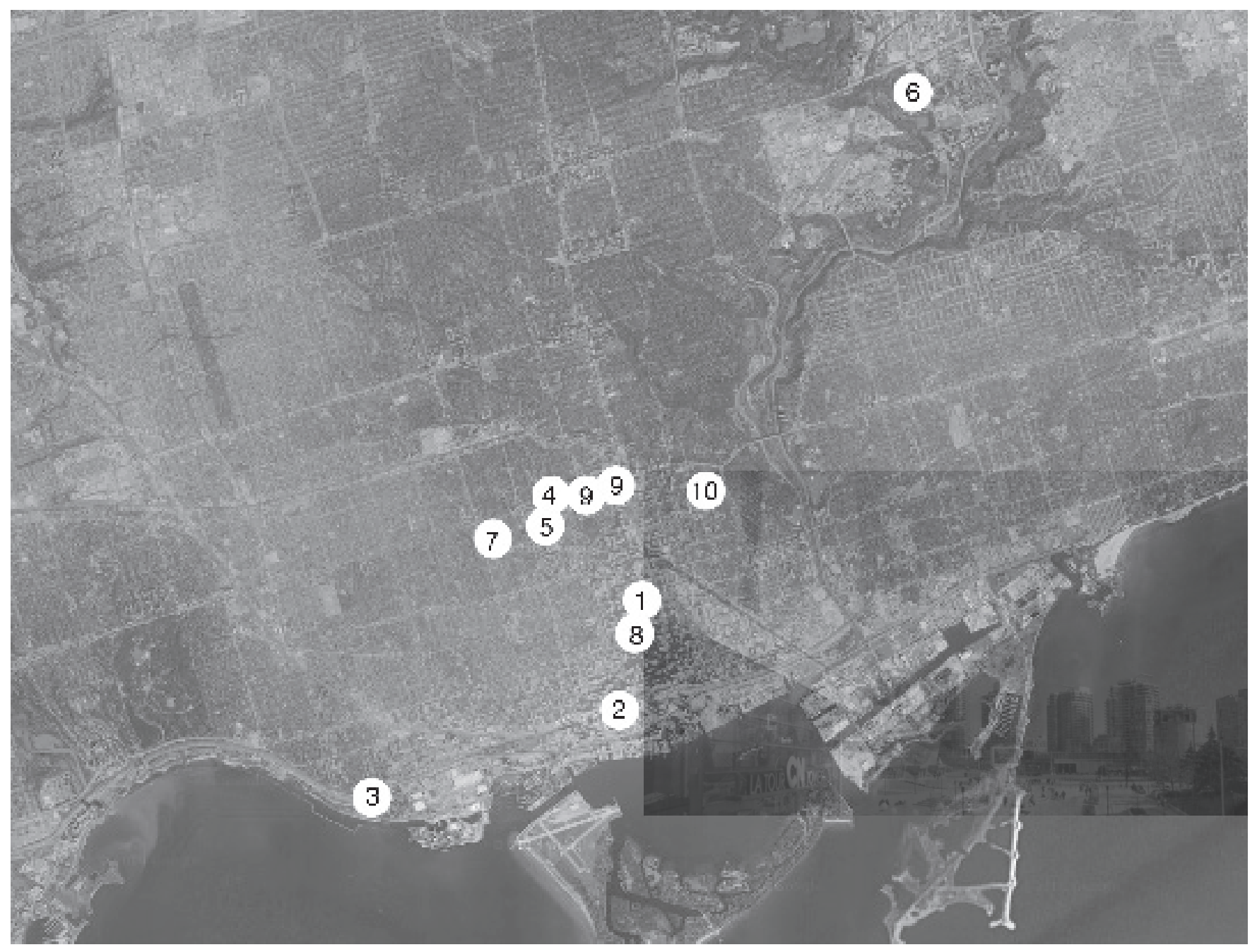

1. New City Hall

2. CN Tower

3. Gardiner Expressway

4. Ontario Institute for Studies in Education

5. Robarts Library

6. Ontario Science Centre

7. Central Technical Art Centre

8. Sheraton Centre

9. Manulife Centre

10. The Collonade

11. St. James Town 


\section{CONSERVING BRUTALIST AND CONCRETE MODERN HERITAGE}

\section{Civic Buildings}

Civic buildings are at the heart of Brutalism. While concrete modern architecture did not conform to any particular type or application, there are many civic concrete modern buildings. The most iconic buildings in Toronto and the best examples of concrete modern civic architecture are New City Hall and the CN Tower. Both structures are monumental testaments to the spirit and hopefulness of Toronto in the postwar era.

New City Hall is a Toronto landmark and it is one of the definitive concrete modern structures in the city. The design for the structure was selected through an international competition held in 1958. The competition spurred a nation-wide conversation about architecture and helped define the architectural taste of a generation. The winner of the competition was Viljo Revell, a Finnish architect. His design remains one of the best examples of concrete modern architecture in the world (Hume, 2007, p. 70). Two curved towers that stand at 27 and 20 storeys frame a "flying saucer" that contains the council chamber. The design "expresses the civic ideal and the democratic spirit that lie at the heart of the modern city" (Hume, 2007, p. 70, Concrete Toronto).

The strength of Revell's design lies in his use of concrete and his interpretation of Brutalism (Hume, 2007, p. 70). Where Brutalist buildings are often both literally and figuratively top down constructions that impose upon individual users, New City Hall elevates the office space above the council chamber in an inversion of the traditional power structure. Furthermore, Revell's use of gentle curves is less "brutal" than the Brutalist structures being constructed at that time. The humanist spirit and democratic nature of Revell's design is unique (Hume, 2007, p. 70, Concrete Toronto) and it encapsulates the spirit of Toronto at the time.

The design of New City Hall is enhanced by its position on Nathan Phillips Square - a large public plaza. The building's setting mirrors the humanism and democracy of Revell's design: the square provides a venue for ice-skating, office workers eating lunch and public demonstrations and protests. 


\section{CONSERVING BRUTALIST AND CONCRETE MODERN HERITAGE}

Like New City Hall, the CN Tower is an iconic Toronto structure and it is also nationally significant. Canadian National Railways built the CN Tower over a period of 40 months and it was opened to the public on June 26,1976 . The construction of the tower used new concrete technology that was current at the time. The use of the continuous pour technique was made possible by a temporary concrete mixing plant that was constructed at the tower's base for the duration of construction (p. 161, Concrete ldeas). When it was built, the CN Tower was the tallest tower in the world - an achievement that was a testament to the strength of Canadian industry and imagination (cntower.com).

The CN Tower was originally designed as the focal point of a major plaza but the rest of the project was never built (McCartney, 2014). Instead, the tower was cut off from the city by railroad tracks and adjacent development. Recently, the relatively small pre-existing plaza at the base of the tower was redesigned and a new sign was erected. The opening of Ripley's Aquarium of Canada in 2013 next to the CN Tower was the catalyst for the renewed attention that has been paid to the base of the structure. Because of this new development and because of the structure's iconic status, the CN Tower continues to be a point of pride and it is a major tourist attraction.

\section{$\underline{\text { Infrastructure }}$}

The Gardiner Expressway is an impressive feat of concrete modern infrastructure that is a testament to 1960 s attitudes to cars and city planning. Built in 1964, the multilane highway is raised above the surface of the city and it serves as an east-west connection for vehicle traffic. The Gardiner is an important transportation connection but it visually and physically cuts the city

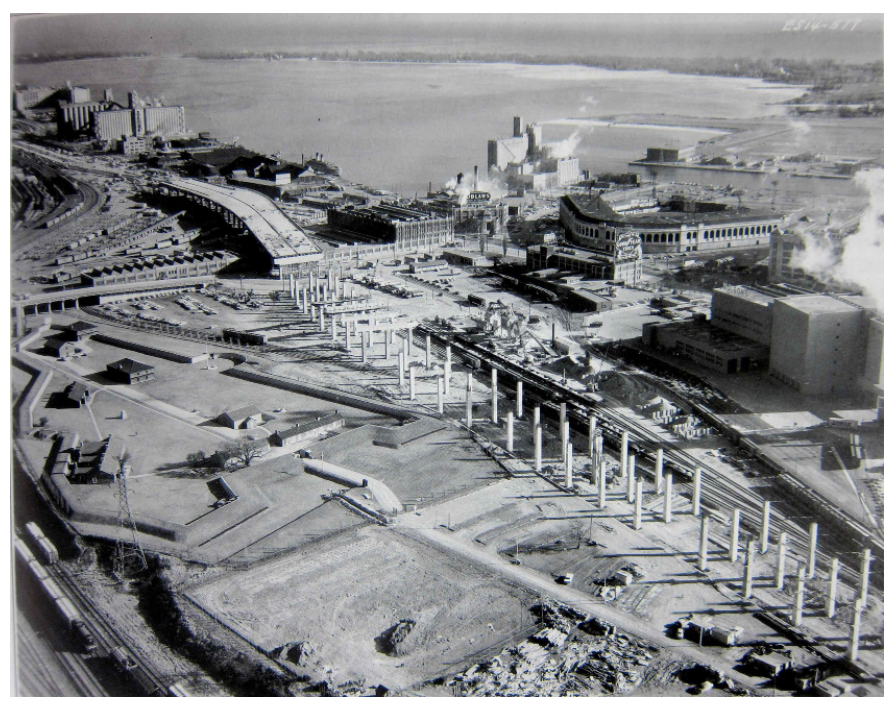
off from the waterfront and is in need of repair. The Gardiner is one of many super-highways 
CONSERVING BRUTALIST AND CONCRETE MODERN HERITAGE

that were built in the postwar period. In mid-century New York, Robert Moses was famous for his endorsement of large-scale transportation infrastructure projects and his disregard for their impact on established communities (McCartney, 2014). Taking his cue from Moses and other men like him, in the 1950s Fred Gardiner "famously demand[ed] that Fort York be relocated so the expressway could remain straight (he had to bend on that one)" (Brook, 2007, p. 182).

In recent years, the Gardiner has been the subject of concern and speculation. In 2000, the Waterfront Toronto Revitalization Taskforce recommended that the city bury a significant portion of the highway that cuts through the downtown (Kane, 2014). Another possibility that is under consideration is that the highway be demolished and replaced with a ground level boulevard that would re-stitch the city to the waterfront (Petricone, 2012, p. 66).

\section{University Buildings}

University campuses all over North America were the testing grounds of new, dynamic architectural styles in the postwar era. In Toronto, Brutalist architecture was produced more fearlessly and with more conviction on university campuses than in the case of civic buildings. The designs for university buildings were more likely to be commissioned from an architect than selected from competition entries, so the architects of university buildings had more freedom to take risks. Throughout history, universities have been sources of creativity and innovation and the postwar liberal consensus provided universities with the resources to invest in architecture. The University of Toronto, Toronto's predominant institution of higher education at the time, has a significant stock of postwar concrete buildings, two of which are the Ontario Institute for Studies in Education (OISE) and Robarts Library.

The Ontario Institute for Studies in Education (OISE) is an imposing Brutalist building. As a department, OISE perfectly encapsulates the hope and vision of the postwar period. The building was constructed in 1969 - a time when education at all levels was a top priority: "OISE was first envisioned by Premier William Davis as an institution for graduate studies in education research. Davis saw OISE as 'an organization to bring about change, a driving force 
CONSERVING BRUTALIST AND CONCRETE MODERN HERITAGE

in Ontario's advance into education for the future" (Martins-Manteiga, 2007, p. 138, Concrete Toronto).

The architecture of the building is a monumental testament to the reverence for education. K.R. Cooper, an architect and developer, designed the building. His design is sophisticated and complex. The building is used for various functions; it has "offices, conference rooms, classrooms, libraries, underground parking and an auditorium," furthermore, subterranean tunnels connect OISE to the subway system (Martins-Manteiga, 2007, p. 138, Concrete Toronto). Cooper masterfully combined different uses into a towering but cohesive building.

Despite OISE's lofty intentions and sophisticated architecture, the public did not appreciate the building's effect on the streetscape. OISE is a concrete mass with a platform, a uniform podium and a narrower tower with windows that are accentuated by raised geometric casings. Cooper softened the brutal nature of the monumental building with landscaping and

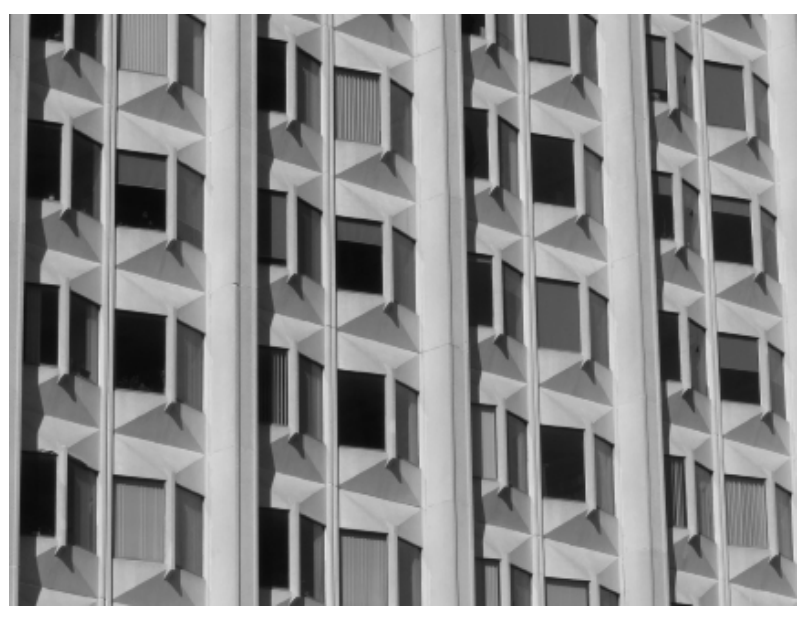
the recessed podium. Nonetheless, the building was condemned in the press as "a "white elephant' and a 'soulless monster'” (Martins-Manteiga, 2007, p. 140, Concrete Toronto). Today, OISE remains a highly functional although often aesthetically underappreciated building.

OISE is a Brutalist building in many ways but the John P. Robarts Library, also at the University of Toronto, is one of the truest examples of Brutalist architecture in Toronto. Many university campuses across the country have Brutalist libraries and this library exemplifies the scale, darkness and monumentality that are associated with the genre.

A late example of concrete modern architecture, Robarts Library, commonly known as "Fort Book," (Averill, 2014) opened in 1974 and critics and the public alike viewed it with disgust. 
CONSERVING BRUTALIST AND CONCRETE MODERN HERITAGE

One critic wrote that Robarts Library "represents everything in architecture that is arrogant and wrong" (Thom cited by Lobsinger, 2007, 167, Concrete Toronto). Nonetheless, it is a wellconstructed building that is dramatic and creative and as such, it was designated as a Heritage B building in 1997 (Lobsinger, 2007, 164, Concrete Toronto).

The University of Toronto invested in the construction of its library as part of an initiative to expand the offerings of higher education to more people. It was a dramatic gesture that was expressed by dramatic architecture. "Robarts Library is a product of planning for the forecasted boom in higher education and the expansion of graduate-level education in the early 1960s" as well as provincial pressure to spend on higher education (Lobsinger, 2007, 164, Concrete Toronto).

\section{Cultural Institutions}

Outside the boundaries of the university, alternative educational venues proliferated in the form of cultural institutions. Cultural institutions, like university buildings, provide space for education to flourish. While the public-service aspect of educational institutions is in line with Brutalist principles, these buildings in Toronto tend to offer a gentler, more playful interpretation of the style. Cultural buildings are important landmarks that call for monumental and creative design. Where university buildings in Toronto were more audacious and provocative, civic buildings and cultural institutions offer a softer, more palatable style that is marked by experimentation with form and dimension and a positive relationship with the surrounding environment.

The promotion of education was achieved not only through traditional classrooms but also through institutions like the Ontario Science Centre. The Science Centre was conceived in 1964 and completed in 1969. Its construction was part of the investment that took place in anticipation of Canada's centennial in 1967 (McClelland and Stewart, 2007, p. 37).

The building has a space-age style, which was popular at the time. The centrepiece of the structure is the planetarium, which is a tilted silver dome surrounded by concrete with a claw- 
CONSERVING BRUTALIST AND CONCRETE MODERN HERITAGE

like metal structure suspended over top. The dome is positioned off-centre and fore-grounded against the backdrop of a long low concrete structure. The dome is reminiscent of New City Hall's satellite-like council chambers. In the case of the Science Centre, the dome is a testament to scientific exploration. The spherical shape of the dome is not just an architectural statement; it is also functional, as the dome houses a planetarium, so it is both a physical and metaphorical reference to space.

The Central Technical Art Centre is not a traditional cultural institution like the Ontario Science Centre but it expresses similar principles. The Central Technical Art Centre is affiliated with Central Technical School and it offers an arts-based curriculum to high school students as well as classes for adults. The provision of artist studio space in a high school setting is unique and the building was a progressive step toward expanding educational offerings.

The architecture of the Central Technical Art Centre was groundbreaking at the time of its construction - it was completed in 1962 making it one of the first cast in place expressive concrete façades constructed in Toronto following the war (McClelland and Stewart, 2007, p. 37). The building design is based around the floors, which are visible in the articulated exterior - the

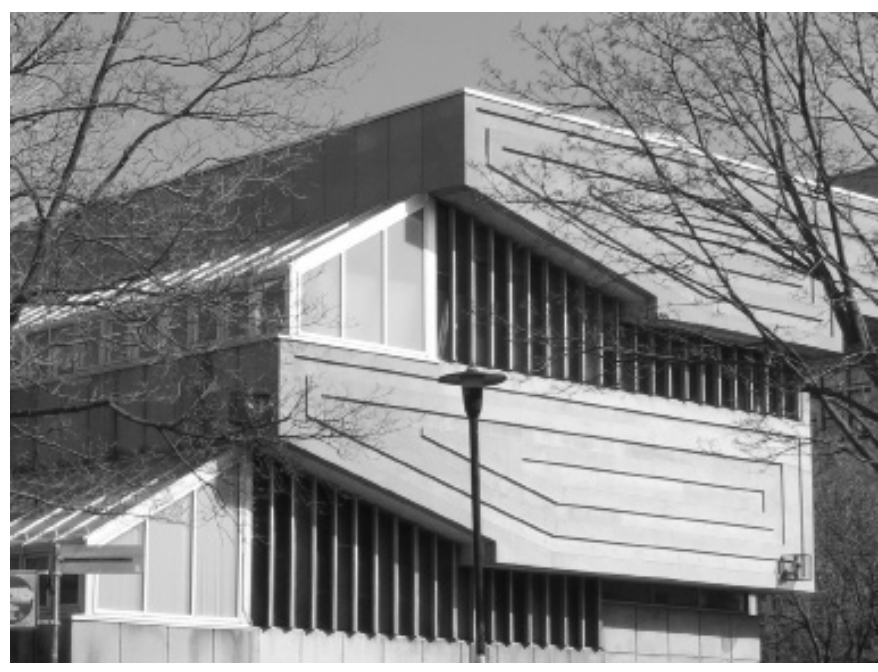
floors are staggered to allow light to flow into the studios. The Central Technical Art Centre is an architecturally significant building that explores the possibilities that concrete offers as a building material. The design of the building is unique because it cleverly responds to the needs of users.

\section{Capitalist Investment}

The 1950s, 60s and 70s in Toronto were a time of civic pride, public investment and the 


\section{CONSERVING BRUTALIST AND CONCRETE MODERN HERITAGE}

promotion of education but they were also a time of suburban sprawl, the dawn of mall culture and the worship of convenience. Many shopping malls, hotels and luxury apartment buildings were built in Toronto at this time. The architecture of these buildings is a clear departure from Brutalism in terms of ethics and, more subtly, style. The harsh elements of Brutalism were replaced in many of these structures with sleekness, elegance and regular proportions but the monumentality and use of concrete remain. While these luxury structures are rooted in consumerism and cater to individual comfort, they resemble their civic, Brutalist cousins in their size and visual force.

The Sheraton Centre has a quintessentially Brutalist façade with its broken-rib pre-cast concrete panels and its monumental form. The Sheraton Centre was built to correspond with New City Hall, which it faces across the expanse of Nathan Phillips Square. While New City Hall represents utility and a major civic use, the Sheraton Centre is a testament to luxury and leisure as its primary use is as a hotel and its secondary uses include shops, restaurants and office space (Stewart and McClelland, 2007, p. 30, Concrete Toronto).

15.

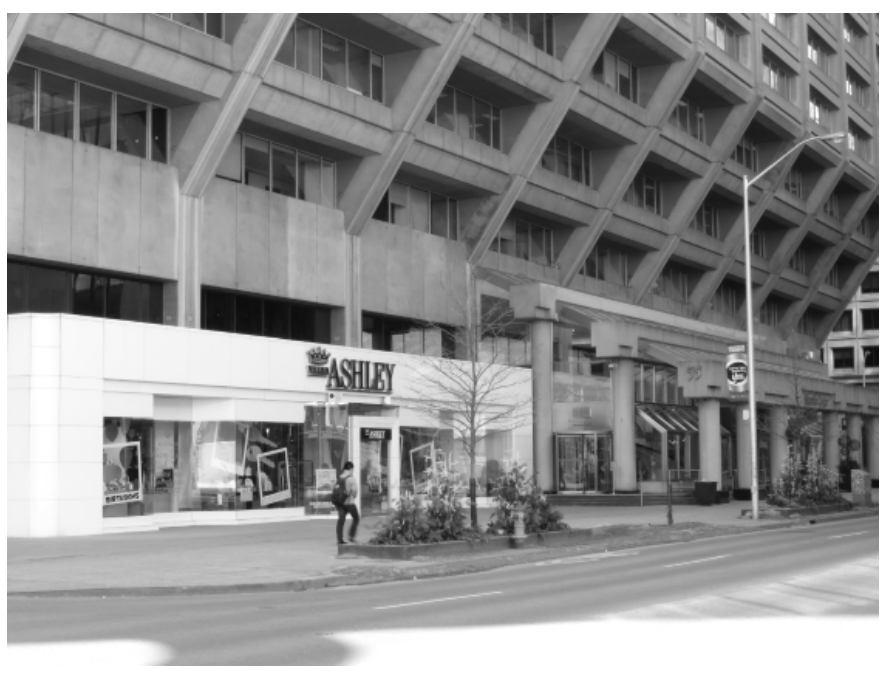

The Manulife Centre is another testament to consumer culture. The Manulife Centre is centrally located in downtown Toronto. It was completed in 1974 and its cultural place in the city has not changed or diminished since then. The ground floor retail connects the building to the city street and relates the structure to the area's retail character. The building is a massive,

51-storey concrete structure (Stewart and McClelland, 2007, p. 29, Concrete Toronto) that is elegant, geometric and proportional. The floors above the retail levels are luxury apartments.

Just west of the Manulife Centre, is the Collonade - another concrete modern, mixed-use 
CONSERVING BRUTALIST AND CONCRETE MODERN HERITAGE

structure that primarily functions as a luxury apartment building. The Collonade commands considerable rents and it houses luxury clothing and jewelry stores on the ground floor. It was one of the first mixed-use buildings in Toronto and its ground floor retail seamlessly blends in with the surrounding context. The Collonade is one of the most sought-after addresses in the city. Luxury, however, comes at a price: "It seems almost medieval to collect $\$ 6,300$ a month for a two-bedroom rental unit in Toronto, despite its mighty-kingdom-like view across Queen's Park toward the lake" (Evans, 2007, p. 116, Concrete Toronto). The structure resembles Le Corbusier's famous L'Unité d'habitation in both its purpose and appearance.

\section{Tower Housing}

Beginning with Le Corbusier's vision for L'Unité d'habitation, postwar concrete mass housing structures have become a feature of cities all over the world. The ubiquitous towers have links to Soviet mass housing, to the idealism of the capital cities Brasilia and Chanigarh and to Hong Kong's super blocks (Stewart, 2011, p. 148). In Toronto, residential concrete towers make up a significant portion of the built form.

The appeal of the tower as a housing model was widely accepted in the 1950s, 60s and 70s although it is rarely recognized today:

Offering modern amenities and conveniences, large suite sizes, as well as unobstructed access to light and air, outdoor community recreation space and 'breathing room' in the context of high-density multiple housing, the modern concrete tower was felt to be the housing model that combined the best standards possible with a responsible use of land and economic means of production (Stewart, 2011, p. 148).

Not only were towers appealing to residents, they also appealed to governments looking to supply social or affordable housing on large scales at low cost.

The tower began with Brutalism and Le Corbusier specifically but this particular type of postwar concrete architecture became a chapter of architectural history unto itself. Concrete towers became popular in the 1960 s and they remained popular for 25 years thereafter. The popularity of concrete high-rise towers was also their death-knell. Mid-century high-rises are so common that they have become mundane and the functionality and utility that they were designed to 


\section{CONSERVING BRUTALIST AND CONCRETE MODERN HERITAGE}

express is no longer considered a desirable aesthetic.

Clusters of high-rise apartment buildings sprung up in Toronto's downtown and periphery in the postwar period. Suburban expansion was rampant in Toronto in the postwar period and high-rise buildings were the primary mode of new-construction dense residential housing on the city's periphery. Greenfield, suburban development was supported in Toronto in the 1950s, 60s and 70s as a progressive form of city building: "It was believed that significant apartment housing was needed in peripheral regions in order to facilitate employment, transit and social objectives" (Stewart, 2008, p. 25). The concept of suburban development is a product of Europe but its implementation in Toronto was influenced by North American Keynesian economics, neo-liberalism and free-market capitalism. While Toronto's high-rise apartment development was part of a larger, international movement, the city stands out as having been defined by its postwar apartment growth: "Between 1950 and 1980, more modernist slab apartment buildings were built in Metropolitan Toronto than anywhere else in North America, particularly in its expanding suburbs" (Stewart, p. 152, Concrete Ideas). Not only were tower neighbourhoods built on the periphery of the city, they were also built downtown on land that was acquired through the demolition of historic buildings. Planners and politicians facilitated this practice because they were "Eager to make up for tax assessments and status lost to the suburbs" (Stewart, 2008, p. 27). St. James Town, for example, is a downtown tower neighbourhood that is located on the site of demolished

16.

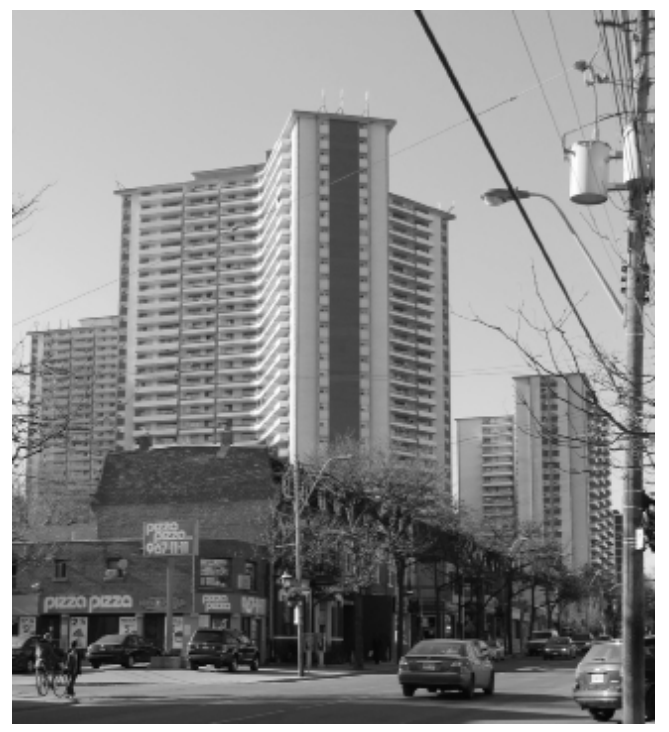

Victorian homes.

Despite the contention behind their construction, Toronto's high-rise neighbourhoods serve an important function as sources of affordable high-density housing. St. James Town, Thorncliffe Park and Flemingdon Park are thriving high-rise neighbourhoods, despite the fact that their buildings are aging. These neighbourhoods are made up of clustered towers that are connected 
CONSERVING BRUTALIST AND CONCRETE MODERN HERITAGE

by greenspace and parks and turn their backs on the street. This neighbourhood design is based on the tower in the park urban design concept, which paired parks, for their beauty and assumed healthiness, with high-density towers. The result of this approach is insular pockets of towers and parks that have no relationship with the surrounding urban context in form, design or sometimes even community. 
CONSERVING BRUTALIST AND CONCRETE MODERN HERITAGE

\begin{tabular}{|c|c|c|}
\hline Building Types & & \\
\hline \multicolumn{3}{|l|}{ Civic Buildings } \\
\hline New City Hall & (17. & $\begin{array}{l}\text { Recommendation: } \\
\text { Civic buildings } \\
\text { should be protected } \\
\text { and maintained by } \\
\text { government. }\end{array}$ \\
\hline CN Tower & & \\
\hline \multicolumn{3}{|l|}{ Infrastructure } \\
\hline Gardiner Expressway & 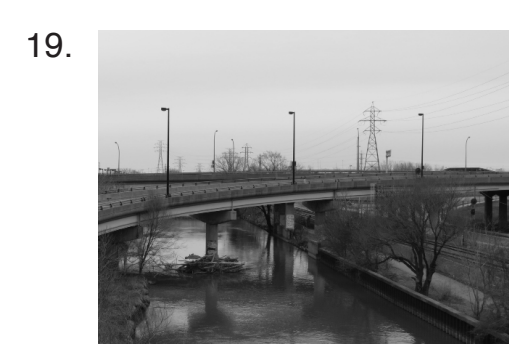 & $\begin{array}{l}\text { Recommendation: } \\
\text { Postwar infrastructure } \\
\text { should be maintained } \\
\text { and torn down and } \\
\text { replaced when } \\
\text { necessary. }\end{array}$ \\
\hline \multicolumn{3}{|l|}{ University Buildings } \\
\hline $\begin{array}{l}\text { Ontario Institute for Studies } \\
\text { in Education } \\
\text { Robarts Library }\end{array}$ & 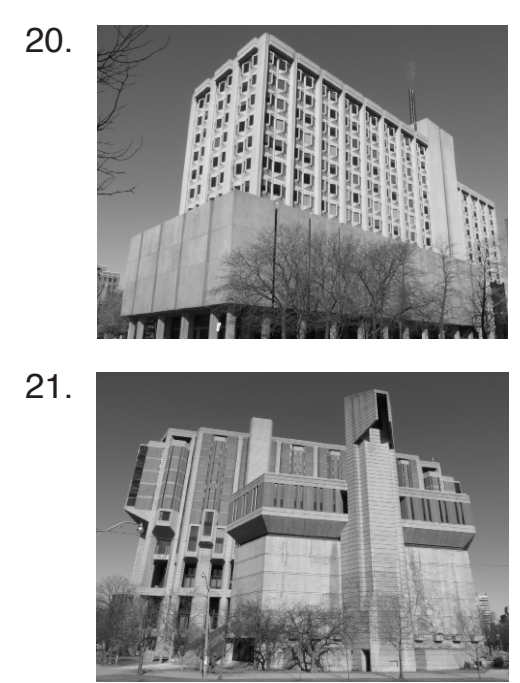 & $\begin{array}{l}\text { Recommendation: } \\
\text { University buildings } \\
\text { should be protected } \\
\text { through policy tools. } \\
\text { Interior redesigns can } \\
\text { be used to update the } \\
\text { buildings and make } \\
\text { them more appealing } \\
\text { and comfortable. } \\
\text { Interior redesigns } \\
\text { should be superficial } \\
\text { and reversible. }\end{array}$ \\
\hline
\end{tabular}


CONSERVING BRUTALIST AND CONCRETE MODERN HERITAGE

\begin{tabular}{|c|c|c|}
\hline \multicolumn{3}{|l|}{ Cultural Institutions } \\
\hline $\begin{array}{l}\text { Ontario Science Centre } \\
\text { Central Technical Art Centre }\end{array}$ & 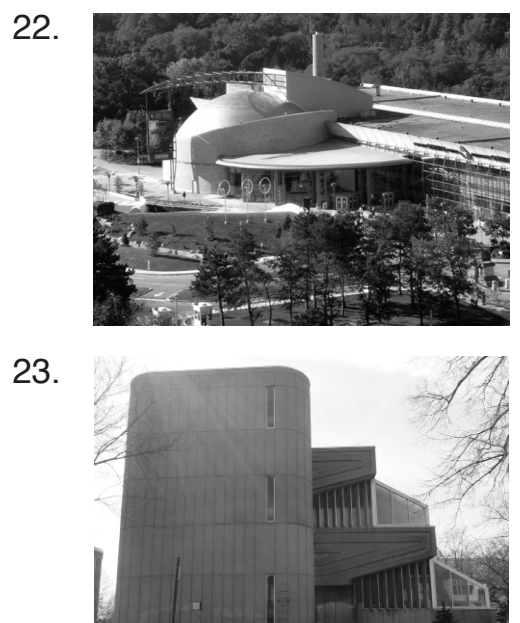 & $\begin{array}{l}\text { Recommendation: } \\
\text { Cultural institutions } \\
\text { should be protected } \\
\text { through policy tools. } \\
\text { Interior redesigns can } \\
\text { be used to update the } \\
\text { buildings and make } \\
\text { them more appealing } \\
\text { and comfortable. } \\
\text { Interior redesigns } \\
\text { should be superficial } \\
\text { and reversible. }\end{array}$ \\
\hline \multicolumn{3}{|l|}{ Captalist Investment } \\
\hline $\begin{array}{l}\text { Sheraton Centre } \\
\text { Manulife Centre } \\
\text { The Collonnade }\end{array}$ & 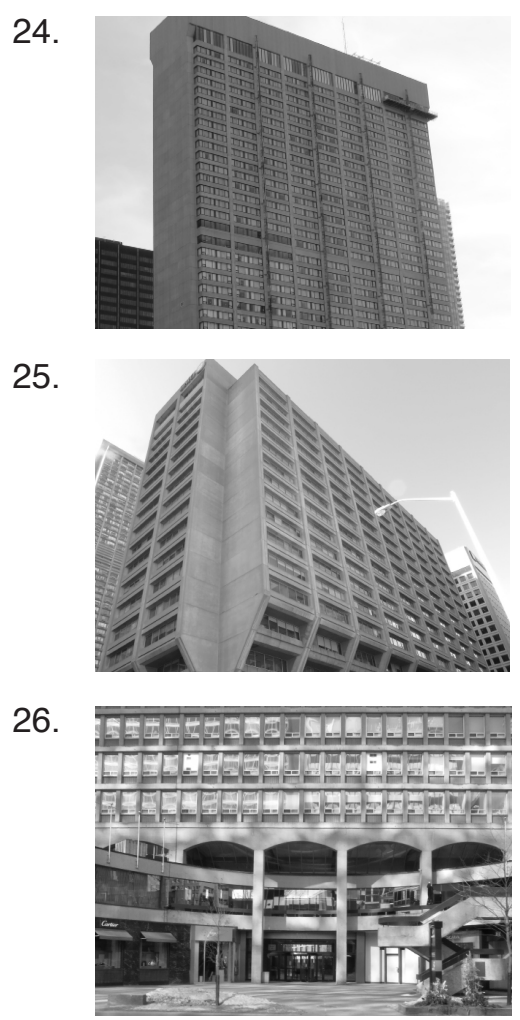 & $\begin{array}{l}\text { Recommendation: } \\
\text { Buildings built through } \\
\text { capitalist investment } \\
\text { should be protected } \\
\text { through policy tools. } \\
\text { Interior redesigns can } \\
\text { be used to update the } \\
\text { buildings and make } \\
\text { them more appealing } \\
\text { and comfortable. } \\
\text { Interior redesigns } \\
\text { can be extensive if } \\
\text { appropriate and the } \\
\text { exterior architecture is } \\
\text { maintained. }\end{array}$ \\
\hline \multicolumn{3}{|l|}{ Tower Housing } \\
\hline St. James Town & Fints & $\begin{array}{l}\text { Recommendation: } \\
\text { Tower housing should } \\
\text { be maintained and } \\
\text { improved through } \\
\text { both city-led and } \\
\text { grassroots intiatives. }\end{array}$ \\
\hline
\end{tabular}




\section{Conservation}

\section{Conserving Brutalist Heritage}

The response to Brutalist buildings is often characterized as being one of popular dislike but there is a growing movement amongst planners, architects and the public to recognize and protect Brutalist and concrete modern buildings. This emerging appreciation for Brutalism is the first step toward a concerted conservation effort but more work is required. Policy tools like the Ontario Heritage Act 1990 and owner-led tools like adaptive reuse need to be considered and applied for Brutalist and concrete modern buildings for appreciation to translate into preservation.

The respect and admiration for Brutalist and concrete modern buildings is a relatively recent phenomenon. Russell Smith (2005) wrote an article in The Globe and Mail that describes the growing support for Brutalism: "Affection for brutalist architecture ... seems to be reaching a pitch. There are initiatives for preserving our ugliest, greyest architecture all over the world - especially Europe - and retrospectives in art books and galleries are all over the place" (L5). Smith goes on to mention the exhibition Brutal and Beautiful: Saving the 20th Century that opened at a London gallery in November 2013. He also cites the books Brutalism: Postwar British Architecture (2011) by Alexander Clement and Cosmic Communist Constructions Photographed (2010) by Frédéric Chaubin as further proof of the shift in attitudes to the movement.

In Canada and the United States, there is a similar, though weaker movement for the preservation of Brutalist and concrete modern heritage. Many of the essays and examples that are drawn on in this paper are from two relatively recent publications that celebrate Brutalism. Clog is a quarterly architecture magazine that is published out of New York, New York and its issue Brutalism (2013) was recently released. This compilation of essays, quotes, statistics and photographs provides a multi-faceted representation of the movement. In Toronto, Michael McClelland and Graeme Stewart edited the book Concrete Toronto: A guidebook to 
CONSERVING BRUTALIST AND CONCRETE MODERN HERITAGE

concrete architecture from the fifties to the seventies, which is a collection of essays and a guide to the city's significant concrete modern buildings. In the summer of 2013 , Toronto's Spacing magazine published an issue that encapsulates the shift in attitudes to Toronto's concrete modern heritage. The issue is titled Stop the Hate! Modernism: The post-war era defines our city - it's about time we learned to finally appreciate it. These publications have communicated the value of Brutalism and concrete modernism to a wide audience and paired with conservation efforts, they will determine the legacy of the movements in Toronto.

The sudden change in the reception of Brutalism and concrete modernism is a product of the current political climate and the passage of time. While the unique conditions of the postwar period have not and hopefully never will be replicated, the global economic crisis has been a time of collective struggle: "Interestingly Brutalism has made something of a comeback in recent years, attributable to a clichéd predictability that says recessions coincide with solidarity, while booms correlate with individualism" (Self, 2013, p. 29, Brutalism). Economic struggle has been a major force in defining the current era but the ramifications that Canada has experienced following the economic crisis have not been as severe as elsewhere. Nonetheless, Brutalism is rapidly gaining popularity in Canada. The reason for the renewed popularity of Brutalism and concrete modernism can also be attributed to the perspective that time has provided. Because time has progressed, Brutalism and concrete modernism have become historical and when viewed through the lens of history, the values and ideas the movements embody are more evident.

\section{Changing Approaches to Conservation}

Toronto has a history of failing to recognize the value of its historical architecture until it is too late. The conservation practices of the postwar period were shortsighted and much of Toronto's Victorian architecture was lost. Brutalist architects were forward-looking and they rejected the past both stylistically and literally. Brutalism emerged as a form of infill but Brutalist projects were not limited to bombed sites: "postwar reconstruction proposals considered the existing city a blank sheet of paper, and it was the logic of the clean slate that governed outlines for 
CONSERVING BRUTALIST AND CONCRETE MODERN HERITAGE

interventions" (Busquets, 2006, p. 265). Postwar reconstruction led to urban renewal policies in North America, which razed historic buildings and replaced them with new construction under the guise of progress. Modernists dismissed the past: "The position of the Modern Urbanism on the old town was clear: the search for new models that would overcome the difficulties of the traditional city led to a denial of "any value" of a social or aesthetic nature" (Busquets, 2007, p. 270).

The position of the modernists on heritage is in sharp contrast with Camillo Sitte's position on heritage at the turn of the century. Sitte respected heritage and he opposed the careless restoration practices of his time. He advocated for minimal interventions into the urban fabric that do not jeopardize the integrity of the traditional city. Sitte's ideas are summarized as follows: "This activity of respect for and promotion of the traditional city, leading to the recovery of monuments and the construction of urban spaces that make them easier to view and enjoy was also to emphasize the propaedeutic value of heritage" (Busquets, 2006, p. 269). Key figures in the modern movement openly mocked Sitte's approach to the city at the Congrès International d'Architecture Moderne (CIAM congresses), which were held from 1928 to 1960. His ideas were considered to be in opposition to the "force of the innovative city created according to the logic of the right angle" (Busquets, 2006, p. 269) that the modern movement was so intent on creating.

In the 1970s, Sitte's work was championed as an alternative to the sweeping destruction of heritage districts that the modern movement proposed. Since the end of the modern movement "The demolition operations and systematic substitutions of the postwar period have evolved toward interventions of conservation and improvement" (Busquets, 2006, p. 272). This resurgence of respect for and appreciation of historical architecture is in sharp contrast with the practices of the preceding era of modernist might (Busquets, 2006, p. 269).

Conservationists today believe that both development and preservation play an important role in shaping cities and adaptive re-use is a popular compromise between these competing 


\section{CONSERVING BRUTALIST AND CONCRETE MODERN HERITAGE}

forces. Many historical buildings of lesser architectural value are being re-appropriated through adaptive re-use: "Reinterpretation of buildings and their capability for recycling, [overrules] the old discrimination between monuments and buildings of "little value"' (Busquets, 2006, p. 274). In the context of Brutalist heritage, adaptive re-use is challenging because Brutalist buildings were often designed to reflect their intended use. Adaptive reuse and preservation should both be used to maintain Brutalist and concrete modern buildings so that they continue to be valued.

\section{Rejection of Modernism}

Both general and academic opinions on modern architecture became negative shortly after the movement's popularity grew. The lack of comfort, embellishment and human scale led to the widespread dislike of concrete modern architecture. Colin Rowe proclaimed the death of modernism in a lecture in which he looked to philosophy to explain the popular rejection of the movement. Rowe (1979) presented a colourful obituary for the modernism:

We may ascribe her death (Modern architecture is surely a she) to the ingenuousness of her temperament. Displaying an extraordinary addiction to towers and completely unconstructed spaces, when young she possessed a high and romantically honorable idea of life and her excess of sensibility could only lead to later chagrin (Rowe, 1979, p. 167).

Rowe identifies the modern movement's emphasis on ethics at the expense of aesthetics as the source of its downfall.

Both concrete modern architecture and Brutalist architecture lost their popularity over time. The concrete high-rise is a symbol of the downfall of modernism but the movement ultimately failed because of its widespread application: "Modernism's alchemistic promise - to transform quantity into quality through abstraction and repetition - has been a failure, a hoax: magic that didn't work. Its ideas, aesthetics, strategies are finished” (Koolhaas, 1995, p. 961). The principles behind Brutalism and modernism were applied on a large-scale through ambitious development projects, many of which failed to achieve their intended impact. Brutalist buildings are not as monolithic or as ubiquitous as concrete modern buildings but the Brutalist aesthetic, while unique, also led to its popular rejection. Architects and designers often appreciate the 
CONSERVING BRUTALIST AND CONCRETE MODERN HERITAGE

creativity of Brutalist style but the public often fails to see the appeal in an intentionally brutal aesthetic.

This popular rejection of a historical architectural style is not an isolated occurrence in Toronto's history. Many modern neighbourhoods, like Regent Park for example, were built in the aftermath of the destruction of Victorian heritage buildings that were officially and popularly condemned. Farewell to Oak Street is a film by the National Film Board of Canada that documents the planning and construction of Regent Park in the 1950s. In the film, the Victorian homes on Oak Street are portrayed as contributing to the poverty of residents. The lack of light and cramped quarters were criticized and juxtaposed with the clean, bright, open apartments of the new, modern Regent Park. This attitude of erasure is not unique to the modern movement: "It is quite usual for there to be a period of eclipse, followed by a phase of rediscovery or reassessment" (Curtis, 1999, p. 13). Today, people have begun to rediscover and reassess Brutalist and concrete modern architecture in the same way that people rediscovered and reassessed Victorian architecture in the 1970s.

Toronto has a legacy of cutting ties with the past and today's common rejection of Brutalism and modernism is an example of this practice. Torontonians have bonded over their shared dislike of the city's modern architecture: “Toronto's famous rejection of modernism has for better or for worse defined much of its collective urban psyche - or cultural myth for the past quarter century" (Stewart, p. 157, Concrete ldeas). Despite ongoing criticism of Toronto's concrete modern architecture, a shift in values has begun to take place and a movement to conserve Brutalist and concrete modern buildings is on the rise.

\section{Policy Tools}

Tool

Provincial Policy Statement 2014

Ontario Heritage Act 1990

Official Plan 2010

Heritage Management Plan 2007
Level of Government

Provincial

Provincial

Municipal

Municipal 
CONSERVING BRUTALIST AND CONCRETE MODERN HERITAGE

For Brutalist and concrete modern buildings to be conserved, they must be legally protected. Heritage conservation is a priority and policy at both the provincial and municipal levels reflects that. The Provincial Policy Statement 2014 establishes that "Significant built heritage resources and significant cultural heritage landscapes shall be conserved" (2.6.1). The specific processes of conservation are outlined in the Ontario Heritage Act 1990, which is the primary legislative tool that is used to protect buildings of cultural heritage value or interest in the province of Ontario. Through the Act, heritage buildings are protected from demolition or removal and alteration unless the Minister approves the demolition or removal or the Board orders the demolition or removal. In Toronto, Brutalist and concrete modern buildings of significant cultural heritage value or interest should be identified and protected using the legislative power of the Ontario Heritage Act 1990.

Buildings can be designated as heritage buildings in three different ways: by the province, the municipality or the minister. Under Part III section 25.2 of the Act, "the minister may prepare heritage standards and guidelines" for the preservation of heritage properties. Buildings that are identified as meeting those standards and guidelines are then reviewed and, if selected, entered into the Ontario Heritage Act Register, which lists properties of cultural heritage value or interest. The entry into the Register must contain a description of the property along with a statement of significance that explains the property's heritage value.

Buildings that are designated under the Ontario Heritage Act 1990 must demonstrate cultural heritage value or interest. The criteria for designating a building are set out in subsection 2 of clause 29 (1) (a) of the Act. Buildings can be designated based on their "design value or physical value", "their historical or associative value" or their "contextual value". A building has "design value or physical value" if it "is a rare, unique, representative or early example of a style, type, expression, material or construction method, displays a high degree of craftsmanship or artistic merit, or demonstrates a high degree of technical or scientific achievement." Many Brutalist and concrete modern buildings can be designated for their design value because of the technological innovation of concrete construction, and the 


\section{CONSERVING BRUTALIST AND CONCRETE MODERN HERITAGE}

experimental and unique design that characterizes such buildings. Another dimension of heritage value that the Act refers to is the "historical value or associative value" of buildings. This value is established if a building:

has direct associations with a theme, event, belief, person, activity, organization or institution that is significant to a community, yields, or has the potential to yield, information that contributes to an understanding of a community or culture, or demonstrates or reflects the work or ideas of an architect, artist, builder, designer or theorist who is significant to a community.

While the design value of Brutalist and concrete modern buildings has been debated, their historical or associative value can be established based on the clear link between the style and the politics, values and historical circumstances of the postwar period. The third dimension of heritage value, "contextual value", is established if a building "is important in defining, maintaining or supporting the character of an area, is physically, functionally, visually or historically linked to its surroundings, or is a landmark." While many Brutalist buildings are not cohesively integrated with their surroundings, they often function as landmarks as is demonstrated, for example, by Robarts Library which is a landmark on the University of Toronto campus. Concrete modern buildings, on the other hand, sometimes do support the character of the surrounding area as the Manulife Centre and the Collonade demonstrate.

In addition to the Ontario Heritage Act 1990, many cities have policy tools to protect their local heritage. In Toronto, section 3.1 .5 of the Official Plan 2010 addresses the city's heritage resources and recommends that they be conserved. The policy states, "Significant heritage resources, will be conserved by listing properties of architectural and/or historic interest on the Inventory of Heritage Properties, designating them and entering into conservation agreements with owners of designated heritage properties." This section of the Plan also states, "Public incentives to encourage the conservation and long-term protection of heritage resources will be created." It is often expensive for owners to maintain designated heritage buildings and incentives, typically in the form of grants, reduce the financial burden on the owners of heritage buildings and ensures that heritage buildings are well maintained. The Plan also addresses the conservation of heritage buildings that are owned by the city, which is particularly important 
CONSERVING BRUTALIST AND CONCRETE MODERN HERITAGE

in the case of Brutalist buildings: "All City owned heritage resources will be conserved and maintained in a state of good repair."

In addition to the policies regarding heritage conservation in the Official Plan 2010, Toronto also has a Heritage Management Plan 2007. This document defines the conservation priorities for the city and emphasizes the importance of awareness and conservation. The goal of the Plan is to "allow conservation efforts to thrive and for heritage to be at the forefront of decisions on the ongoing development and maintenance of Toronto's structures and landscapes" ( $p$. 18). To achieve these goals, the Plan includes a framework for identifying and managing the city's heritage resources and goals are established for conservation, increasing awareness and establishing funding for conservation (p. 18). The Plan takes an integrated approach to heritage, which expands the traditional definition of heritage to include, among other things, "a variety of types and styles, including modern architecture" (p. 16). The Heritage Management Plan 2007 picks up where more general policies leave off by establishing tools, approaches and goals for heritage conservation in Toronto.

Many of Toronto's Brutalist buildings are under threat of demolition, alteration or abandonment due to their increasing age. However, some theorists believe that the application of traditional preservation tools, like the Ontario Heritage Act 1990, to Brutalist buildings goes against the principles of the movement. Brutalist buildings were intended to be functional first and aesthetic second: "If there was a fate worse than death for Brutalism, surely it is preservation, or even ghastlier, sympathetic and considerate restoration" (Dellaria, 2013, p.164). Despite this theoretical inconsistency, Brutalism is an important moment in cultural and architectural history and if Brutalist buildings are not formally preserved, they will not remain. By promoting awareness, applying policy tools, establishing grant programs and innovating new solutions, heritage planners will succeed in protecting Brutalist and concrete modern building for future generations to appreciate. 


\section{CONSERVING BRUTALIST AND CONCRETE MODERN HERITAGE}

\section{Best Practices}

The conservation of Brutalist and concrete modern buildings can be achieved through advocacy and the subsequent use of policy tools and adaptive re-use techniques. Best practices from around the world present a way forward by demonstrating the success of particular conservation methods. Planners, architects and the public can learn from conservation efforts that are taking place globally and then apply those techniques in the local, Toronto context. If applied well, policy tools and adaptive re-use techniques can breathe new life into old buildings and in doing so, secure their futures as functional and admired elements of the city.

\section{Friedman Study Center}

The Friedman Study Center occupies the lower three floors of the Sciences Library, a Brutalist building on the Brown University campus. Like many Brutalist libraries, the Study Centre is an imposing concrete mass that was underappreciated and underused by students. To improve the appeal of

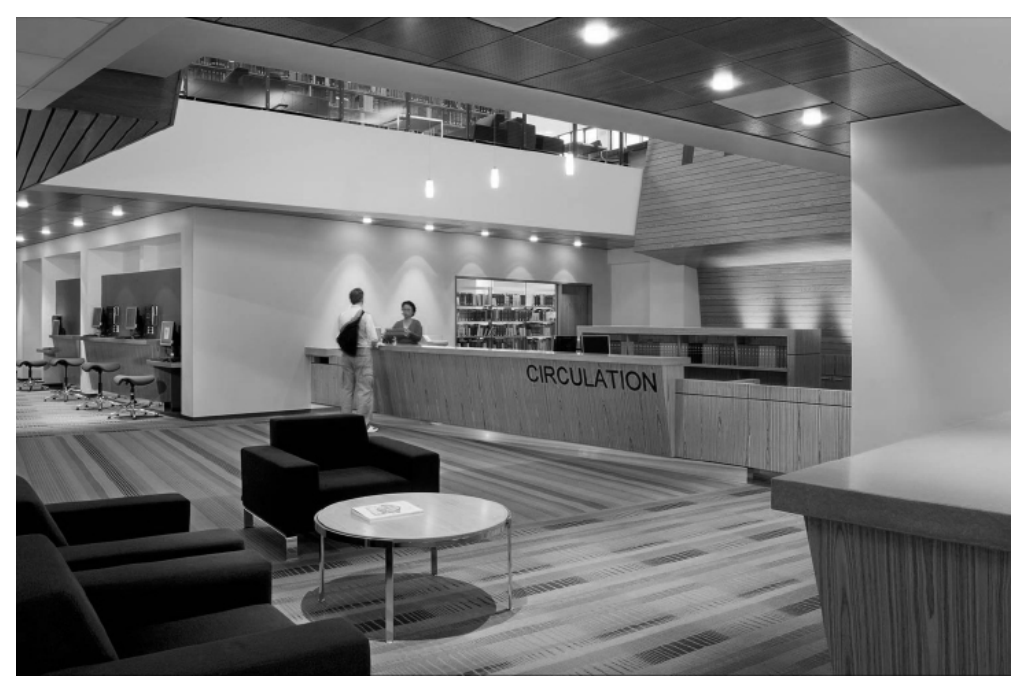
the Study Centre, in 2005 the university renovated the interior of the space by bringing in new finishes and textiles while remaining true to the architecture. The superficial nature of the project was key to its success: "Its strong formal character and materiality are preserved as a background for our interventions. Our design was largely organizational" (Architecture Research Office, 2013, 145, Brutalism). This interior makeover updated the Study Centre to make it a functional and active space but the changes are reversible and do not threaten the integrity of the historical architecture. The minimalism of this intervention is inspiring because it is grounded in the present needs of the building's users and at the same time, it preserves the building's architecture for posterity. 


\section{CONSERVING BRUTALIST AND CONCRETE MODERN HERITAGE}

\section{Westwick}

Jeanne van Heeswijk is a Dutch artist who has successfully redefined the potential of modern high-rise apartment buildings. Van Heeswijk staged a grassroots arts project in Westwick - a modern tower neighbourhood in the Netherlands. She co-opted a dilapidated shopping mall and transformed it into a dynamic community hub:

Displaying a guerilla-like resourcefulness, she turned the shopping center into a cultural, arts, and social center. She played simultaneously on different levels, energizing the local inhabitants but also convincing the stately Boijmans Aluseum of Rotterdam to use the shopping center as a temporary auxiliary museum, organizing local handicraft fairs as well as inviting internationally renowned architects, artists, and thinkers to visit and work (Provoost and Vanistiphout, 2007, p. 42).

This project was realized through a bottom-up movement - the community reclaimed their architecture. This project provides an example of how people can mobilize to re-imagine and animate modern high-rise neighbourhoods. Much of the discourse on tower neighbourhoods is negative and they are often tolerated or replaced but Van Heeswijk has proposed an alternative. Westwick is a precedent for the preservation and adaptive reuse of high-rises:

All the cliches about their anonymity, cultural poverty, ugliness, and economic hopelessness were proven wrong. The inhabitants became proud of their area and less inclined to follow top-down policies. Intellectuals from outside the neighborhood were forced to see and understand these areas as not just abstractions (Provoost and Vanistiphout, 2007, p. 42).

\section{Tower Renewal Project}

The Tower Renewal Project is an initiative that the City of Toronto has taken on in partnership with E.R.A. Architects. The purpose of the project is to upgrade the city's existing stock of concrete modern high-rise towers. The program recognizes the potential value of these buildings and seeks to solve the issues of "rapidly growing poverty and socio-economic polarization, and poor building performance responsible for significant greenhouse gas production" (Stewart, p. 152, Concrete Ideas). The Tower Renewal Project builds on successes in Europe where energy-efficient renovations of tower buildings have proven successful and desirable to urban dwellers (Stewart, p.155, Concrete Ideas).

The failure of modern architecture was in its execution and the Tower Renewal Project intends 
to alter towers so that they can realize the progressive intentions with which they were built. Rather than re-cladding towers and making other cosmetic alterations, the Tower Renewal Project, like any good preservation effort, maintains the spirit of the architecture. Although the buildings that the project targets do not have significant architectural value, they are maintained because they fulfill an important function.

\section{Guggenheim Museum in Bilboa}

Bilboa is a city that was divided by

a massive highway infrastructure project and the city suffered from the fragmentation of its urban landscape. To reanimate the city, Frank Gehry designed the Guggenheim Museum Bilboa as a modern iconic structure that is framed by the highway. By redefining the landscape surrounding the highway, Gehry was able to show the infrastructure in a new light and bring people and attention to an area that had previously been derelict (Busquets, 2007, p. 41).

This approach to solving the problems caused by a large piece of concrete infrastructure is interesting because it considers the space surrounding the highway rather than the highway itself. The project helped draw people to the area and it boosted the local economy by increasing tourism (Busquets, 2007, p. 41). Many other cities have followed Bilbao's example and used iconic architectural insertions to redirect the conversation surrounding a contested urban space. This approach is useful in the context of concrete modern infrastructure projects because it is an affordable solution that redefines the architectural context rather than the architecture of the specific structure being addressed. 
CONSERVING BRUTALIST AND CONCRETE MODERN HERITAGE

\section{Recommendations}

These recommendations draw on international best practices and present general approaches that planners can take to conserve postwar concrete architecture in Toronto and the world. Different types of Brutalist and concrete modern buildings call for different approaches to their futures. A balance of preservation, renovation and adaptive re-use will help Toronto achieve a textured urban fabric that speaks to the best elements of historical architectural styles.

\section{Civic Buildings}

Civic buildings provide important services to the public. Therefore, civic buildings should be updated and modernized as needed rather than preserved at the sacrifice of function. The Brutalist movement was founded based on the principles of efficiency and expediency over aesthetics. Government is, however, the steward of our collective heritage and that responsibility should be taken seriously. Civic buildings are often larger, grander and more visible than other types of buildings and they express more clearly the public's self image than residential buildings, office towers or shopping complexes. Therefore, civic buildings in general are some of the most important buildings to recognize and protect. Brutalist civic buildings represent a large portion of the civic buildings in Toronto and they should be valued and updated through interior redesigns. This will insure that they continue to be iconic and functional elements of the city. The interior redesign of the Friedman Study Centre at Brown University is an example of the minimal, yet impactful approach that should be taken to update significant Brutalist and concrete modern buildings.

\section{Infrastructure}

Values have changed since the postwar period and high-speed vehicular traffic and sprawling suburbs no longer motivate urban planning. Many of the large highways and freeways that were built in the 1950s, 60s and 70s divided cities and cut off access to their waterfronts. Moving forward, highways like Toronto's Gardiner Expressway must be re-thought and better integrated into the urban fabric. Vehicular traffic still needs to be accommodated through largescale infrastructure but that infrastructure should be safe, functional and cohesively integrated 


\section{CONSERVING BRUTALIST AND CONCRETE MODERN HERITAGE}

into the urban fabric.

To better integrate concrete modern highway infrastructure, highways should be replaced with at grade boulevards or buried under ground. Another, more affordable option is to redefine the space surrounding highways by building beneath them, like in the case of the Bilbao Guggenheim museum, and establishing connections that work around the barriers they create.

\section{University Buildings}

Universities have some of the best

examples of Brutalist and concrete modern architecture and these buildings should be recognized and preserved. Universities often have high quality, monumental architecture that contributes beauty and history to the city. The University of

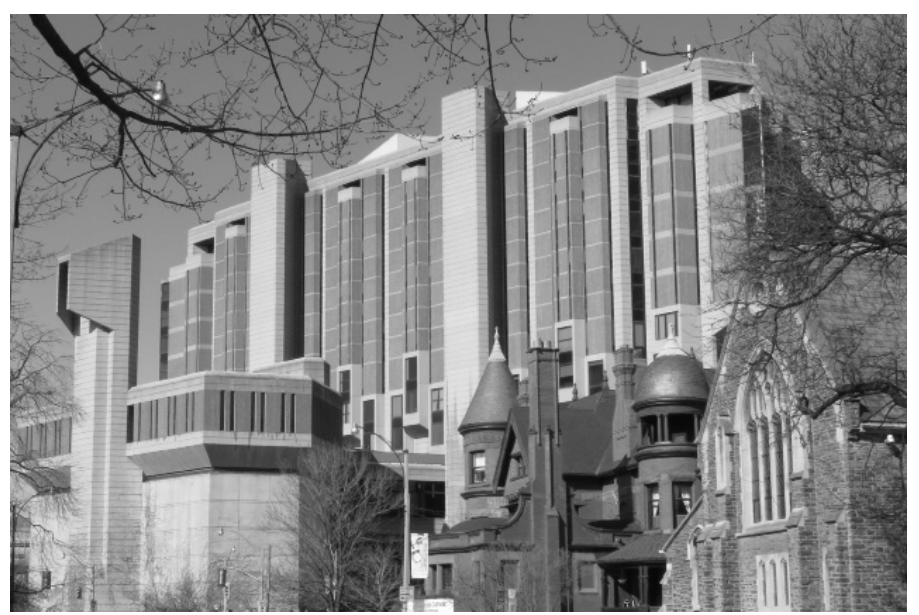

Toronto has many quality examples of postwar Brutalist and concrete modern architecture that should be preserved and maintained. The campus has significant architecture from many different eras and structures from the postwar era are important contributions to this landscape. The Brutalist Robarts Library has already been designated as a heritage building and the campus has several other buildings from the postwar era that would benefit from the same protection. Universities, like government, are stewards of our collective history and they have the additional responsibility of protecting our intellectual and artistic history.

\section{Cultural Institutions}

Cultural institutions are similar to universities in that they often have significant architecture and share a responsibility to protect our intellectual and artistic history. Brutalist and concrete modern cultural institutions should be recognized and preserved for their significant contribution to Toronto's urban landscape. These buildings should also be maintained and protected because they often serve unique and valuable functions that are not provided 
elsewhere.

\section{Capitalist Investment}

Capitalist investment has produced some grand and striking examples of concrete modern architecture. Shopping malls and hotels cater to consumers and express the trends of the eras in which they are built. The owners of such buildings are motivated by profit and they do not have as much motivation to protect architectural heritage as governments and universities do. Concrete modern buildings are, however, appealing and many of them have retained their popularity with consumers. The Manulife Centre, for example, continues to be a stunning building that offers an upscale retail experience. Shopping malls and hotels are often maintained, renovated and torn down based on the shifting needs of consumers and businesses. Many of these buildings should be formally preserved by the city to ensure that their continued relevance is not determined by changing attitudes and trends. The renovation and adaptive reuse of these buildings should be permitted through interior renovations that alter the finishes and other superficial design elements of the structures without dramatically changing their architecture. Interior redesigns can both highlight the appeal of concrete architecture and cater to current tastes and trends. Many buildings that were constructed to cater to consumers have already undergone extensive interior redesigns to maintain their appeal and therefore increase profits. Fortunately, the exteriors of these buildings are, for the most part, still intact because concrete architecture resists surface treatments.

\section{Tower Housing}

Ontario's Condo Act 1998 made condominium buildings more affordable to construct than rental housing. As a result of this policy change, purpose-built rental housing has not been built in the city in recent years. Toronto, therefore, has a lack of affordable rental housing and it is important to preserve its existing purpose-built rental housing. High-rise towers are, however, starting to age and they need to be updated and maintained in order to remain functional. The Tower Renewal Project is an excellent initiative that the city has put forward to upgrade the existing high-rise rental housing stock. 
CONSERVING BRUTALIST AND CONCRETE MODERN HERITAGE

Despite its affordability and functionality, tower housing has been criticized for being unattractive and isolating. To connect these neighbourhoods to the surrounding urban fabric the Tower Renewal Project has recommended that the zoning of these areas be relaxed to encourage a mix of uses. To increase the attractiveness of these areas murals can be painted on the outside of buildings to make their facades more

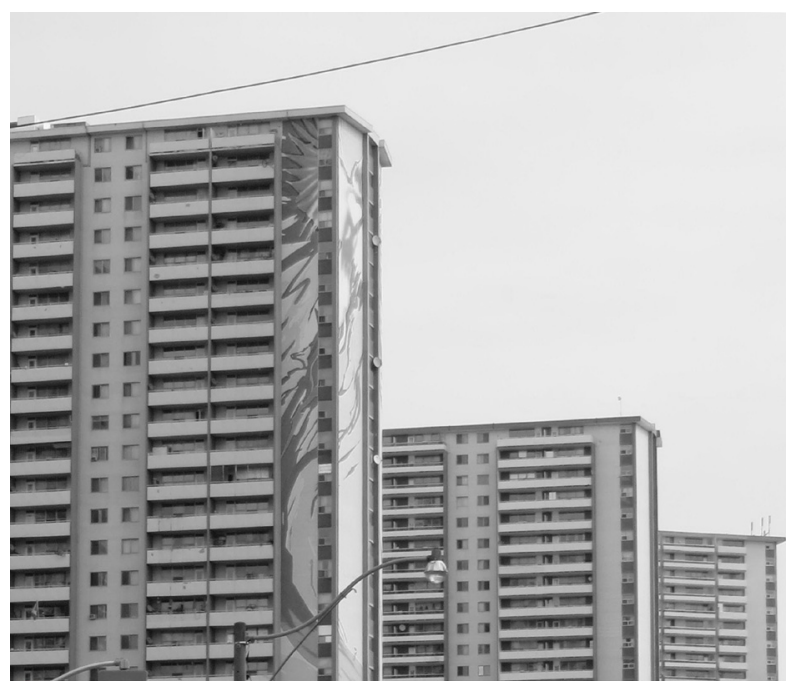
attractive and unique. In addition to efforts to re-imagine the exteriors of high-rises, residents often re-imagine their interiors. Highrise: The Towers in the World, World in the Towers is a collaborative documentary project produced by the National Film Board of Canada that has documented the colour and vibrancy of private living spaces in towers all over the world. While policy tools cannot determine how people inhabit buildings, it should be recognized that highrises can house creative and unique spaces.

Tower neighbourhoods do not have the architectural or cultural merit to warrant their preservation through the Ontario Heritage Act 1990 but they should be maintained and upgraded because they provide quality affordable rental housing. These buildings should be better connected to the surrounding urban fabric and creatively re-imagined when possible. Despite their lack of architectural merit, these buildings are functional and they provide the opportunity for people to create customized and unique living spaces. 


\section{Conclusion}

Brutalism and concrete modernism are undergoing a cultural renaissance and heritage planners should use the emerging conversation around Brutalist and modernist buildings to leverage support for their conservation. The architects, planners and builders of the postwar era changed the face of Toronto and it is important that those same actors today are stewards of the city's modern architectural heritage.

This guide presents a jumping off point that establishes the grounds for conservation. The exploration of a variety of architectural and historical themes as well as the presentation of several tools and examples of conservation best practices are useful to establish a planning rationale and a way forward. However, there remains more work to be done. Toronto is one of many cities internationally that are facing the challenge of managing the futures of Brutalist and concrete modern buildings. New best practices are being tested all over the world and their broader application has yet to be seen. The contents of this paper are by no means exhaustive and the work to conserve Brutalist and concrete modern heritage is ongoing.

At this early stage in the conservation process, advocacy is essential. Brutalist and concrete modern buildings are a testament to the political, cultural and aesthetic values of the postwar era and many of those values are still current today. If people recognize the social and cultural dimensions of Brutalist buildings, they will come to appreciate them. Furthermore, many of these buildings are structurally unique and express the mutability of concrete. If the "historical value or associative value" and "design value or physical value" (Ontario Heritage Act 1990) of Brutalist buildings are recognized, they will be defended by the public and planners alike and preserved for generations to come. 
CONSERVING BRUTALIST AND CONCRETE MODERN HERITAGE

References

Averill, H. (n.d.). Forty Years of "Fort Book": The Story of Robarts Library. Retrieved March 26, 2014, from http://heritage.utoronto.ca/exhibits/robarts-library

Brasilia. (n.d.). Retrieved from http://whc.unesco.org/en/list/445

Brutalism. (2013). Brooklyn: Clog Publications.

Canada City Population History: Montreal, Ottawa, Toronto \& Vancouver. (n.d.). Retrieved from http://www.demographia.com/db-cancityhist.htm

Chandigarh Tourism - The Hub of North India. (n.d.). Retrieved from http://chandigarhtourism. gov.in/

Cizek, K. (Director). (2009). Highrise: The towers in the world, world in the towers [Video]. Retrieved March 18, 2014, from http://highrise.nfb.ca/

Crosby, T. (2011). The New Brutalism. October, 136, 17-18. doi: 10.1162/OCTO_a_00033 Curtis, W. J. (1994). Denys Lasdun: Architecture, city, landscape. London: Phaidon.

The Independent Group. (n.d.). Retrieved March 19, 2014, from http://independentgroup.org. uk/index.html

Jencks, C. (2005). The iconic building. New York, NY: Rizzoli.

Kane, L. (2014, February 5). Gardiner Expressway: A brief history of Toronto's 'superhighway'. The Toronto Star.

Kingwell, M. (2008). Concrete reveries: Consciousness and the city. New York: Viking.

Koolhaas, R., Mau, B., Sigler, J., \& Werlemann, H. (1998). Small, medium, large, extra-large: Office for Metropolitan Architecture, Rem Koolhaas, and Bruce Mau. New York, NY: Monacelli Press.

La Tour CN Tower: History. (n.d.). Retrieved from http://www.cntower.ca/en-ca/about-us/ history/astounding.html

LeGates, R. T., \& Stout, F. (2000). A contemporary city. In The city reader. London: Routledge. Lissitzky, E. (1984). Russia: An architecture for world revolution. Cambridge, Mass: M.I.T. Press.

McCartney, S. (2014, January 21). Line 1: Key Buildings with Urban Synergies. Lecture presented at Urban Design in Ryerson University, Toronto.

McClelland, M., \& Stewart, G. (Eds.). (2007). Concrete Toronto: A guidebook to concrete architecture from the fifties to the seventies. Toronto: Coach House Books and E.R.A. Architects.

McLean, G. (Director). (1953). Farewell to Oak Street [Video]. Retrieved March 1, 2014, from https://www.nfb.ca/film/farewell_oak_street 
CONSERVING BRUTALIST AND CONCRETE MODERN HERITAGE

Office for Urbanism, Goldsmith Borgal and Company Architects Ltd, Greer, W., Gersovitz Moss, F., Stovel, H., \& Tung, A. (2007). Heritage Management Plan Phase 1 (pp. 1-101). Toronto: Heritage Preservation Services.

Ontario Heritage Act, R.S.O. 1990, c. 0.18.

Petricone, P., Baird, G., H., J. M., \& Waldheim, C. (2012). Concrete ideas: Material to shape a city. London: Thames \& Hudson.

Provincial Policy Statement: Issued under section 3 of the Planning Act (p. 2.6.1). (2014).

Toronto, ON: Ministry of Municipal Affairs and Housing.

Scully, V. (1962). Louis I. Kahn (Masters of Contemporary Architecture). New York, NY: George Braziller.

Smith, R. (2013, November 8). Feeling warm and fuzzy about concrete. The Globe and Mail, p. L5.

Smithson, A., \& Smithson, P. (2011). Alison and Peter Smithson from Architectural Digest 1957. MIT Press Journal, 136, 37-37.

Smithson, A., Smithson, P., Drew, J. B., \& Fry, E. M. (2011). Conversation on Brutalism. October, 136, 38-46. doi: 10.1162/OCTO_a_00039

Solomon, L. (2007). Toronto sprawls: A history. Toronto: University of Toronto Press.

Spacing: Toronto Urbanism Uncovered (Summer 2013 ed.). (n.d.). Toronto.

Stewart, G. (2008). The Suburban Tower and Toronto's Legacy of Modern Housing. Docomomo, 39, 23-29.

Stewart, M. (1972). Keynes and after. London: Penguin Books.

Twombly, R. (Ed.). (2003). Louis Khan: Essential texts. New York, NY: W.W. Norton \& Company.

Voyce, A. (1948). Russian architecture, trends in nationalism and modernism. New York: Philosophical Library.

Wright, G. (2010). Toronto Official Plan (p. 3.1.5). Toronto, ON: Toronto City Planning. 